\title{
Loss of Ptf1a Leads to a Widespread Cell-Fate Misspecification in the Brainstem, Affecting the Development of Somatosensory and Viscerosensory Nuclei
}

\author{
Igor Y. Iskusnykh, ${ }^{1}$ Ekaterina Y. Steshina, ${ }^{1}$ and Victor V. Chizhikov ${ }^{1,2}$ \\ ${ }^{1}$ Department of Anatomy and Neurobiology and ${ }^{2}$ The Neuroscience Institute, University of Tennessee Health Science Center, Memphis, Tennessee 38163
}

The brainstem contains diverse neuronal populations that regulate a wide range of processes vital to the organism. Proper cell-fate specification decisions are critical to achieve neuronal diversity in the CNS, but the mechanisms regulating cell-fate specification in the developing brainstem are poorly understood. Previously, it has been shown that basic helix-loop-helix transcription factor Ptfla is required for the differentiation and survival of neurons of the inferior olivary and cochlear brainstem nuclei, which contribute to motor coordination and sound processing, respectively. In this study, we show that the loss of Ptfla compromises the development of the nucleus of the solitary tract, which processes viscerosensory information, and the spinal and principal trigeminal nuclei, which integrate somatosensory information of the face. Combining genetic fate-mapping, birth-dating, and gene expression studies, we found that at least a subset of brainstem abnormalities in $P_{t f 1 a^{-/-}}$mice are mediated by a dramatic cell-fate misspecification in rhombomeres 2-7, which results in the production of supernumerary viscerosensory and somatosensory neurons of the Lmxlb lineage at the expense of $\mathrm{Pax} 2{ }^{+}$GABAergic viscerosensory and somatosensory neurons, and inferior olivary neurons. Our data identify Ptfla as a major regulator of cell-fate specification decisions in the developing brainstem, and as a previously unrecognized developmental regulator of both viscerosensory and somatosensory brainstem nuclei.

Key words: cell-fate specification; hindbrain; human mid-hindbrain malformation disorders; mouse; neuronal progenitors

Significance Statement

Cell-fate specification decisions are critical for normal CNS development. Although extensively studied in the cerebellum and spinal cord, the mechanisms mediating cell-fate decisions in the brainstem, which regulates a wide range of processes vital to the organism, remain largely unknown. Here we identified mouse Ptfl $a$ as a novel regulator of cell-fate decisions during both early and late brainstem neurogenesis, which are critical for proper development of several major classes of brainstem cells, including neurons of the somatosensory and viscerosensory nuclei. Since loss-of-function PTF1A mutations were described in human patients, we suggest Ptfla-dependent cell-fate misspecification as a novel mechanism of human brainstem pathology.

\section{Introduction}

Brainstem neurons control several vital body functions. In particular, neurons of the nucleus of the solitary tract (nTs) integrate viscerocensory information regulating the activity of the respiratory, cardiovascular, and digestive organs; principal sensory tri-

\footnotetext{
Received July 2, 2015; revised Jan. 20, 2016; accepted Jan. 22, 2016.

Author contributions: V.V.C. designed research; I.Y.I., E.Y.S., and V.V.C. performed research; I.Y.I., E.Y.S., and V.V.C. analyzed data; V.V.C. wrote the paper.

This work was supported by National Institutes of Health Grant R21-NS-077163 to VC and by the Neuroscience Institute of the University of Tennessee Health Science Center. We thank C.V. Wright (Vanderbilt University Medical Center, Nashville, TN), M. Magnuson (Vanderbilt University School of Medicine, Nashville, TN), J.F. Brunet (IBENS, Paris, France), M. Goulding (Salk Institute, La Jolla, CA), H. Edlund (University of Umea, Umea, Sweden), F.M. Zhou (University of Tennessee Health Science Center), E. Hedlund and T. Perlmann (Karolinska Institute, Stockholm, Sweden), and S. Arber (University of Basel, Basel, Switzerland) for mice and reagents; and K.J. Millen (Seattle Children's), and W.E. Armstrong, J.M. Ross, L. Fremuth, C.J. Bohl, K.M. Hamre, and M. Ennis (University of Tennessee Health Science (enter) for helpful discussions and valuable comments on the manuscript.
}

geminal nuclei $(\mathrm{PrV})$ and spinal trigeminal nuclei $(\mathrm{SpV})$ process and relay somatosensory information of the face; inferior olivary nuclei (ION) contribute to motor coordination; and cochlear nuclei process sounds (Woolsey, 1990; Ruigrok and Cella, 1995; Blessing, 1997; Pickles, 2015). Previous studies revealed that at least a subset of $\mathrm{nTs}, \mathrm{PrV}, \mathrm{SpV}, \mathrm{ION}$, and cochlear neurons arise from ventricular zone (VZ) progenitors in the alar plate of early rhombomeres ( $\mathrm{rh}$ ) 2-7, and as development proceeds, migrate to their final destinations (Farago et al., 2006; Oury et al., 2006; Yamada et al., 2007; Fujiyama et al., 2009; D’Autréaux et al., 2011;

Correspondence should be addressed to Victor V. Chizhikov, Department of Anatomy and Neurobiology, University of Tennessee Health Science Center, 855 Monroe Avenue, Link Building, Suite 515, Memphis, TN 38163. E-mail: vchizhik@uthsc.edu.

DOI:10.1523/JNEUROSCI.2526-15.2016

Copyright $\odot 2016$ the authors $\quad 0270-6474 / 16 / 362691-20 \$ 15.00 / 0$ 


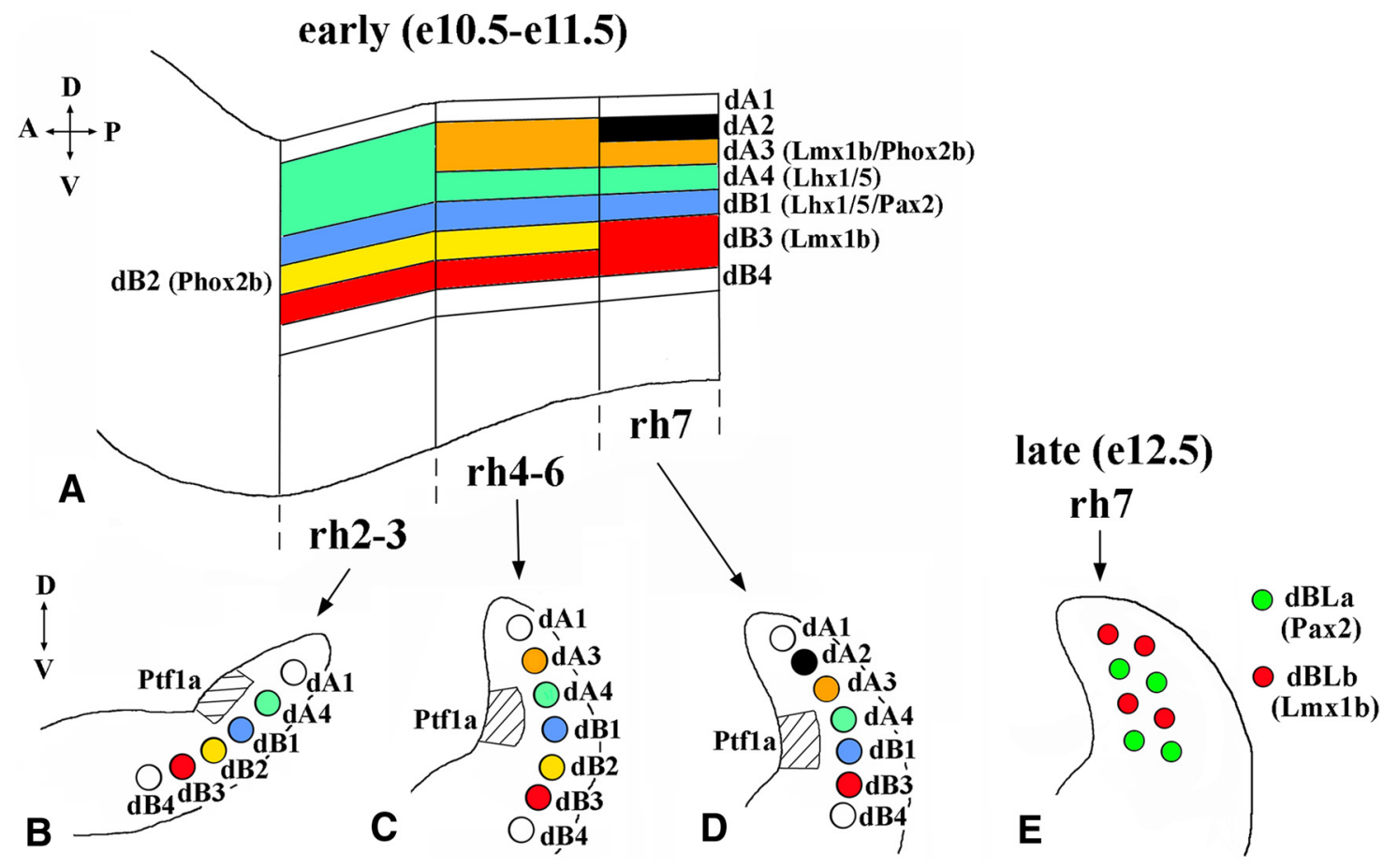

Figure 1. Summary of neuronal subtypes arising during early and late waves of neurogenesis in rh2-7. A, Side view of E10.5-E11.5 hindbrain with $\mathrm{dA}$ and $\mathrm{dB}$ neuronal populations extending through rh2-7. Specific markers for some of these populations are shown based on the data in studies by Sieber et al., 2007 and Storm et al., 2009. The dorsal-ventral (D-V) and anterior-posterior $(A-P)$ axes are labeled. $\boldsymbol{B}-\boldsymbol{D}$, Schematics of transverse sections of E10.5-E11.5 hindbrain taken at the level of rh2-3 $(\boldsymbol{B})$, rh4 $-6(\boldsymbol{C})$, and rh 7 (D). The dorsal part of each hemisection is shown. Ptf1a expression domain in the VZ, located adjacent to dA4 and dB1 neurons, is shown as a hatched area, based on the study by Sieber et al. (2007) and Storm et al. (2009). The D-V axis is labeled. $\boldsymbol{E}$, Schematic of transverse section of E12.5 rh7, showing dBLa and dBLb neurons arising in a salt-and-pepper pattern from a broad domain of the dorsal VZ during late neurogenesis.

Gray, 2013). The mechanisms regulating the development of dorsally derived brainstem neurons, including the mechanisms of their cell-fate specification, however, remain poorly understood.

Based on the expression of transcription factors, eight newborn neuronal populations, named $\mathrm{dA} 1-4$ and $\mathrm{dB} 1-4$, were described in dorsal mouse rh2-7 at embryonic days (E) 10.5-11.5, at the beginning of neurogenesis in the dorsal hindbrain (Fig. $1 A-D$; Sieber et al., 2007). Some of these populations, such as dA4 and $\mathrm{dB} 1$, extend through rh2-7, while others, such as dA3, are present only in some rhombomeres (Sieber et al., 2007; Storm et al., 2009). In contrast to $\mathrm{rh} 2-6$, where $\mathrm{dA} / \mathrm{dB}$ neurons arise throughout neurogenesis, in rh7, dBLa and dBLb neurons arise in a salt-and-pepper pattern from the dorsal VZ after E12 (Fig. 1E; Sieber et al., 2007). Fate-mapping and gene expression studies identified dA3 cells as differentiating Lmx $1 b^{+} /$Phox $2 b^{+}$neurons of the nTS, dA4 cells of the caudal brainstem as newborn ION neurons, and dBLb cells as Lmx1b ${ }^{+} \mathrm{SpV}$ neurons (Sieber et al., 2007; Storm et al., 2009; D'Autréaux et al., 2011), while the eventual fates of most other $\mathrm{dA} / \mathrm{dB}$ populations, as well as $\mathrm{dBLa}$ cells, remain unknown.

Recently, several regulators of hindbrain cell-fate decisions were identified, including homeodomain and basic helix-loophelix (bHLH) transcription factors Phox2b, Olig3, and Lbx1, which are necessary for the specification of $\mathrm{dA} 3 \mathrm{Lmxlb}^{+}$/ Phox $2 \mathrm{~b}^{+}$nTs neurons, dA4 ION neurons, and dBLb Lmx1b ${ }^{+}$ SpV neurons, respectively (Sieber et al., 2007; Storm et al., 2009; D'Autréaux et al., 2011). Another bHLH transcription factor, Ptfla, is transiently expressed in a restricted domain of the dorsal VZ, which extends through rh2-7 (Fig. $1 B-D$; Yamada et al., 2007, Fujiyama et al., 2009; Storm et al., 2009), and also in the cerebellum, which arises from dorsal rh1 (Hoshino et al., 2005).
Loss of Ptfla leads to cerebellar agenesis and prevents formation of the ION and dorsal cochlear nuclei. In $P t f 1 a^{-1-}$ mice, an increased number of apoptotic cells was detected, suggesting that excessive cell death contributes to the development of hindbrain pathology in the absence of Ptfla (Hoshino et al., 2005; Yamada et al., 2007; Fujiyama et al., 2009). More recently, however, we and others (Pascual et al., 2007; Millen et al., 2014; Yamada et al., 2014) found that $P t f 1 a^{-/-}$cerebellar agenesis is largely caused by a cell-fate misspecification in dorsal rh1. Currently, it remains poorly understood whether, in the hindbrain, Ptfla regulates cell-fate decisions beyond rh1, and it is unknown whether this gene is required for the development of brainstem cells other than neurons of the ION and cochlear nuclei.

In this study, by performing genetic fate-mapping in mice, we identify Ptfla as a previously unrecognized developmental regulator of both somatosensory ( $\mathrm{SpV}$ and $\mathrm{PrV}$ ) and viscerosensory (nTs) nuclei. Our analysis revealed that an early and widespread cell-fate misspecification in rh2-7 underlies at least some brainstem abnormalities in $\mathrm{Ptfl} \mathrm{a}^{-1-}$ mice. Since loss-of-function PTF1A mutations were described in human patients with hindbrain malformation disorders (Sellick et al., 2004), our data also suggest misspecification of neurons originating from the rh2-7 $\mathrm{VZ}$ as a novel mechanism of human brainstem pathology.

\section{Materials and Methods}

Animals. We used Ptf1a ${ }^{\text {Cre }}$ (Kawaguchi et al., 2002), Ptf1a ${ }^{Y F P}$ (Burlison et al., 2008), ROSA26-LacZ (Soriano, 1999), ROSA26-YFP (Srinivas et al., 2001), Tau- $n L a c Z$ reporter [which labels neuronal progeny of Creexpressing cells by nuclear $\beta$-galactosidase ( $\beta$-gal) expression, referred to as $n L a c Z$ reporter throughout this article; Hippenmeyer et al., 2005], and Gad67-GFP (Chattopadhyaya et al., 2004) alleles. Because the Ptf1a protein-coding sequence is replaced by Cre or YFP in Ptfla Cre and 
Ptfla ${ }^{Y F P}$ alleles, respectively (Kawaguchi et al., 2002; Burlison et al., 2008), they are Ptfla-null alleles. In this study, we used Ptf1a ${ }^{C r e / C r e}$ and $P t f 1 a^{C r e / Y F P}$ embryos for the analysis of hindbrain development and fate mapping of the progeny of Ptfla-expressing cells in the absence of Ptfla function. All mice used in this study were maintained on a mixed genetic background and were genotyped as previously described (Soriano, 1999; Srinivas et al., 2001; Kawaguchi et al., 2002; Hippenmeyer et al., 2005; Burlison et al., 2008). Noon of the day of the plug was designated as E0.5. For birth-dating experiments, pregnant mice were intraperitoneally injected with BrdU at a concentration of $50 \mathrm{mg} / \mathrm{kg}$. Both male and female embryos were studied. All animal experiments were approved by the Institutional Animal Care and Use Committee.

Immunohistochemistry. Immunohistochemistry was performed as previously described (Swanson et al., 2010; Millen et al., 2014). Briefly, embryos were fixed in $4 \%$ paraformaldehyde for $2-12 \mathrm{~h}$ at $4^{\circ} \mathrm{C}$, sunk in $30 \%$ sucrose, embedded in optimum cutting temperature compound, and sectioned on a cryostat. Cryosections were washed in PBS, blocked in PBS containing $1 \%$ normal goat serum and $0.1 \%$ Triton X-100, and incubated with primary antibodies overnight at $4^{\circ} \mathrm{C}$. Then, sections were washed in PBS and incubated with secondary antibodies for $1 \mathrm{~h}$ at room temperature. The following primary antibodies were used: rabbit antiPax2 (Zymed), anti-Phox2b (Pattyn et al., 1997), anti-Ptfla (H. Edlund, University of Umea, Umea, Sweden), anti-activated caspase 3 (Promega), anti- $\beta$-galactosidase (M.P. Chapel), and anti-Tlx3 antibodies (M. Goulding, Salk Institute, La Jolla, CA), mouse anti-Lhx1/5 antibody (Developmental Studies Hybridoma Bank), goat anti-Lmxla antibody (Santa Cruz Biotechnology), guinea pig anti-Lmx1b antibody (E. Hedlund and T. Perlmann, Karolinska Institute, Stockholm, Sweden), chick anti- $\beta$-galactosidase (Abcam), and anti-GFP antibody, which also recognizes yellow fluorescent protein (YFP; Abcam). Species-appropriate fluorescent dye-conjugated secondary antibodies were purchased from Life Technologies and Jackson ImmunoResearch.

BrdU-labeled cells were detected by immunohistochemistry with primary rat anti-BrdU (Abcam) and secondary goat anti-rat fluorescent dye-conjugated antibodies (Life Technologies). For BrdU detection, embryos were processed and sections were treated exactly as described for immunohistochemistry with other antibodies above, except before blocking in PBS with normal goat serum and Triton, sections were incubated in $2 \mathrm{~N} \mathrm{HCl}$ for $20 \mathrm{~min}$ at $37^{\circ} \mathrm{C}$ and rinsed in $0.1 \mathrm{M}$ borate buffer, $\mathrm{pH}$ 8.5. Double or triple labeling using anti-BrdU, anti- $\beta$-galactosidase, and anti-Lmx1b or anti-Pax2 antibodies was performed sequentially. Sections were first incubated with anti- $\beta$-galactosidase and anti-Lmx1b or anti-Pax 2 primary antibodies and their secondary antibodies. Then, sections were treated with $\mathrm{HCl}$, and anti-BrdU antibodies were applied. Some sections were counterstained with DAPI (Sigma-Aldrich) to visualize cell nuclei. Images were taken using a Zeiss AxioImager Z1 microscope equipped with an AxioCam MRc camera, and figure panels were assembled in Photoshop.

Anatomy, measurements, and statistical analysis. At least three embryos of each genotype at each developmental stage were analyzed. For each embryo, the entire hindbrain was tangentially serially sectioned at $12 \mu \mathrm{m}$, and all sections were evaluated under a microscope. Similar numbers of sections were placed on each slide to more easily identify the position of each section along the anterior-posterior axis of the hindbrain. Rhombomeric units were identified using morphological landmarks such as exit points of cranial nerves (Cordes, 2001) and hindbrain nuclei, as previously described (Sieber et al., 2007; Storm et al., 2009). In addition, molecular markers were used to confirm the rhombomeric identity of E11.5 sections. At E11.5, rh7 dorsal VZ contains $\mathrm{Ngn}^{+}{ }^{+}$cells (dA2 progenitors) that are not present in more anterior rhombomeres (Landsberg et al., 2005, Yamada et al., 2007; Storm et al., 2009). E11.5 rh1 contains $\mathrm{Lmxla}^{+} \mathrm{c} 3$ cells that are not present in more posterior rhombomeres (Chizhikov et al., 2006). By staining every fifth serial section of caudal hindbrain with an anti-Ngn1 antibody and every fifth serial section of rostral hindbrain with an anti-Lmxla antibody, we confirmed the rhombomeric identity of rh7 and rh2 sections selected for molecular analysis (data not shown). At E14.5, rh7 was defined as a hindbrain segment caudal to the facial nucleus, as previously described (Sieber et al., 2007). In $P t f 1 a^{-/-}$embryos, the position and extent of this nucleus along the anterior-posterior axis of the hindbrain was not affected (data not shown). To evaluate the positions of specific brainstem nuclei, every fifth serial section of the hindbrain was stained with cresyl violet (Schambra, 2008). Then, the remaining sections, spanning the entire brainstem along its anterior-posterior axis, were colabeled with antibodies to more specifically identify and analyze the $\mathrm{PrV}$, nTs, and SpV nuclei (Sieber et al., 2007; Dai et al., 2008; Storm et al., 2009; Xiang et al., 2012), as described in the Results section. In Ptfla mutants, the PrV, nTs, and SpV nuclei formed at appropriate positions in the brainstem, but, as described in the Results section, their neuronal composition was affected. For cell counts, sections from control and $P t f 1 a^{-/-}$littermates were carefully selected to ensure that they were taken from comparable anterior-posterior levels. For consistency, cell counts were performed on three sections per embryo, separated by $48 \mu \mathrm{m}$ from each other. In most cases, we quantified the cells of interest using immunohistochemistry against nuclear markers (e.g., Lmx1b, Phox $2 b$, Pax2, and nuclear $\beta$-gal), and cell numbers were determined by counting positive nuclei. To evaluate apoptosis, we quantified Casp $3^{+}$cells. All raw cell counts were corrected by multiplying the raw values by the Abercrombie (1946) correction factor, determined as $T / T+h$, where $T$ is section thickness and $h$ is mean nuclear diameter (or mean diameter of Casp $3^{+}$cell bodies). For each cell type, $h$ was determined by measuring 30 cells from three different embryos of each genotype at each developmental stage, as previously described (Jahagirdar and Wagner, 2010). For clarity, cell counts in Ptf $1 a^{-1-}$ embryos were normalized to the counts in control embryos, which were set as 1 , as previously described (Huang et al., 2010; Sudarov et al., 2011; Millen et al., 2014). Quantitative data are expressed as the mean \pm SD. Statistical significance was determined by two-tailed $t$ test. $p<0.05$ was considered to be statistically significant.

\section{Results}

In early $P t f 1 a^{-/-}$rh7, Ptfla-expressing progenitors produce $\mathrm{dA} 3$ and $\mathrm{dB} 3$ neurons instead of $\mathrm{dA} 4$ and $\mathrm{dB} 1$ neurons

To investigate whether Ptfla regulates cell-fate decisions in the hindbrain beyond rh1, we analyzed rh2-7 of $P t f 1 a^{-1-}$ embryos beginning at E11.5, when early-born neurons are generated and were described as $\mathrm{dA} / \mathrm{dB}$ populations (Fig. $1 A-D$; Sieber et al., 2007; Storm et al., 2009). Since cells arising from Ptfla-expressing progenitors turn Ptfla expression off once they initiate neuronal differentiation and exit the VZ (Yamada et al., 2007; Fujiyama et al., 2009; Storm et al., 2009), to visualize the Ptf1a lineage, we used Ptfla $a^{\mathrm{Cre} /+} ;$ ROSA-YFP (control) and Ptfla ${ }^{\text {Cre/Cre }}$;ROSA-YFP $\left(P t f 1 a^{-/-}\right)$embryos, in which $P t f 1 a$-expressing progenitors in the hindbrain $\mathrm{VZ}$ and their progeny are permanently labeled with YFP expression from the ROSA-YFP allele (Srinivas et al., 2001).

In rh7 of control E11.5 Ptf1a ${ }^{\mathrm{Cre} /+}$;ROSA-YFP embryos, Lhx1/ $5^{+} / \mathrm{Pax} 2^{-} \mathrm{dA} 4$ and $\mathrm{Lhx} 1 / 5^{+} / \mathrm{Pax} 2^{+} \mathrm{dB} 1$ neurons were $\mathrm{YFP}^{+}$, supporting previous studies suggesting that these populations originate from Ptfla-expressing progenitors (Fig. $2 A, C$; Storm et al., 2009). The vast majority of Lmx $1 b^{+} /$Phox $2 b^{+}$dA3 neurons, which dorsally flank dA4 neurons, and $\mathrm{Lmx} 1 \mathrm{~b}^{+} / \mathrm{Phox} 2 \mathrm{~b}^{-} \mathrm{dB} 3$ neurons, which ventrally flank $\mathrm{dB} 1$ neurons (Figs. $1 D, 2 \mathrm{~A}, \mathrm{~F}$; Sieber et al., 2007; Storm et al., 2009), were YFP ${ }^{-}$in control rh7 (Fig. 2J,k,m). Although in $P t f 1 a^{C r e /+} ; R O S A-Y F P$ rh7, we occasionally observed $\mathrm{Lmx} 1 \mathrm{~b}^{+} / \mathrm{Phox} 2 \mathrm{~b}^{+} / \mathrm{YFP}^{+}$cells, the number of these cells was very small (a few cells per section; Fig. $2 k-l^{\prime \prime}$ ). Thus, during early neurogenesis, in wild-type rh7, Ptfla-expressing progenitors mostly produce $\mathrm{dA} 4$ and $\mathrm{dB} 1$ neurons.

In contrast to wild-type embryos, Lhx1/5/Pax2 immunostaining did not reveal any dA4 or dB1 neurons in $\mathrm{Ptfla}^{-/-}$rh7 (Fig. $2 A, B$, white arrowhead and arrow). Non-numerous $\operatorname{Lhx} 1 / 5^{+}$ cells found in lateral $\mathrm{rh} 7$ of E11.5 Ptfla ${ }^{-/-}$mutants (Fig. $2 B$, open arrowhead, D, arrowhead) were $\mathrm{YFP}^{-}$in $\mathrm{Ptf1} \mathrm{a}^{\mathrm{Cre} / \mathrm{Cre}} ; \mathrm{ROSA}-\mathrm{YFP}$ embryos (Fig. $2 e$, arrowheads) and, therefore, likely, were ventrally migrated dA 2 cells (which originate from $\mathrm{Ptfla}^{-}$progeni- 

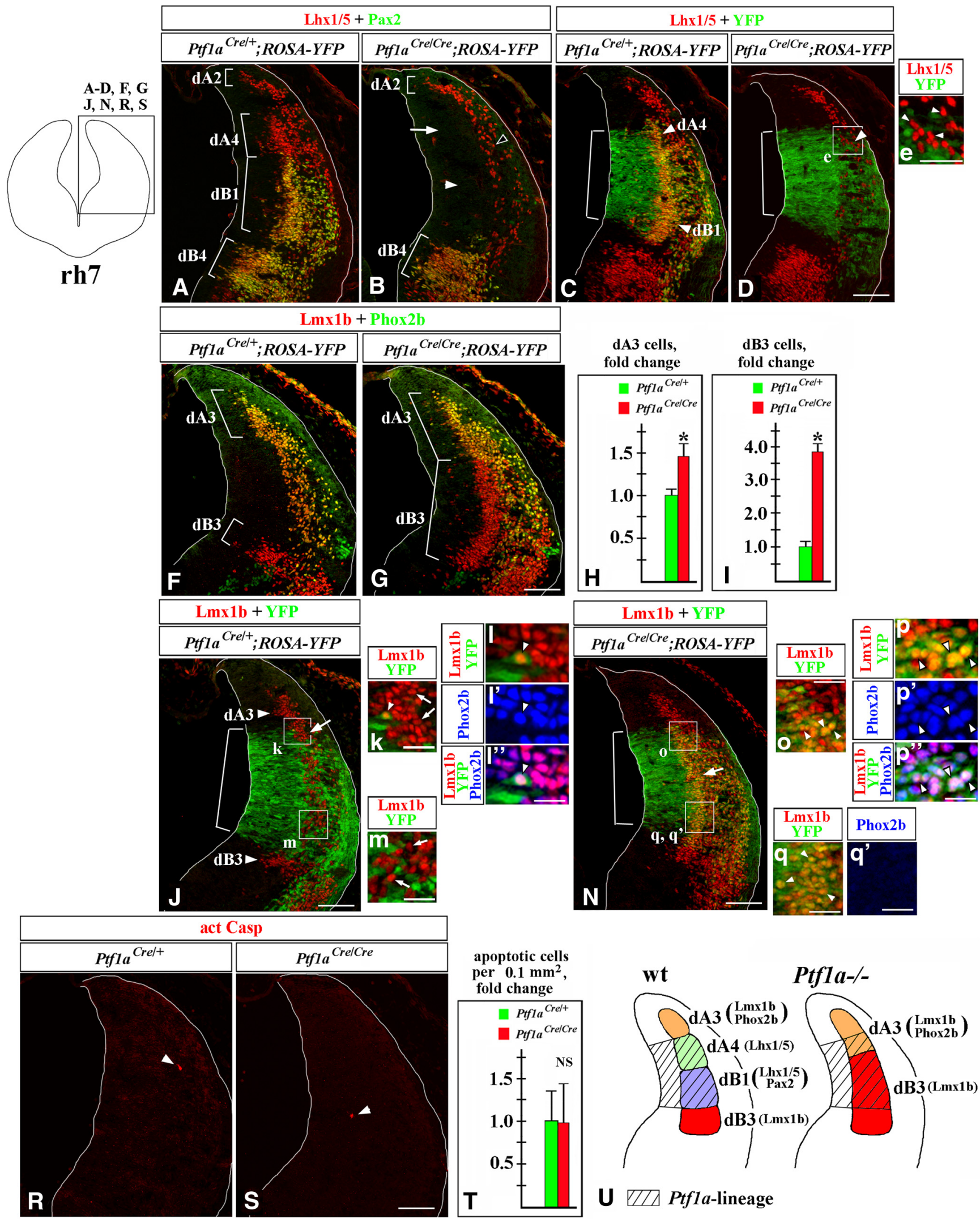

Figure 2. In E11.5 Ptf1a ${ }^{-/}$rh7, Ptf1a-expressing progenitors produce $\mathrm{dA} 3$ and $\mathrm{dB} 3$ neurons instead of $\mathrm{dA} 4$ and dB1 neurons. Transverse sections of E11.5 rh7 with genotypes and antibody markers indicated. Low-magnification panels correspond to the region boxed in the rh7 schematic in the top left corner. Magnified regions $\left(\boldsymbol{e}, \boldsymbol{k}, \boldsymbol{m}, \boldsymbol{0}, \boldsymbol{q}, \boldsymbol{q}^{\prime}\right)$ correspond to areas boxed in related data panels. $\boldsymbol{I}-\boldsymbol{I}^{\prime \prime}$ and $\boldsymbol{p}-\boldsymbol{p} \boldsymbol{p}$ show higher magnification of cells, pointed out by arrowheads in $\boldsymbol{k}$ and $\boldsymbol{O}$, respectively. Brackets in $\boldsymbol{A}, \boldsymbol{B}, \boldsymbol{F}$, and $\boldsymbol{G}$ indicate the positions along the dorsal-ventral axis at which specific neuronal populations emerge. Brackets in $C, D, J$, and $\boldsymbol{N}$ indicate the dorsal-ventral extent of YFP expression in the VZ, which was not significantly different between $P t f 1 a^{\text {(ree/ }} ;$;ROSA-YFP

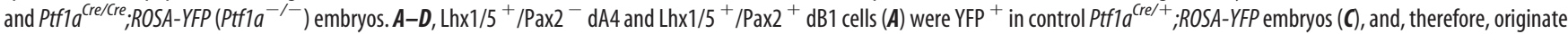
from Ptf1a-expressing progenitors. $B$, In Ptf1a ${ }^{-/-}$rh7, neither dA4 (arrow) nor dB1 (arrowhead) are present. A small group of $\mathrm{Lhx}_{1 / 5^{+}}$cells present in lateral (Figure legend continues.) 
tors located dorsal to the Ptfla-expressing VZ; Storm et al., 2009) rather than dA4 cells. Strikingly, in Ptf1a ${ }^{-1-}$ rh7, dA3 cells expanded ventrally, while dB3 cells expanded dorsally (Fig. 2F, G), populating areas occupied by $\mathrm{dA} 4$ and $\mathrm{dB} 1$ neurons in control rh7 (Fig. $2 A$ ). Cell counts revealed a $>3.5$-fold increase in the number of dB3 cells $\left(p=8.2 \times 10^{-5}\right)$ and almost a $50 \%$ increase in the number of dA3 cells $(p=0.0016)$ in Ptf1a $a^{-/-}$embryos compared with control littermates (Fig. $2 \mathrm{H}, I$ ). In contrast to control rh7, many $\mathrm{Lmxlb}^{+}$cells were $\mathrm{YFP}^{+}$in $\mathrm{Ptfla}^{\mathrm{Cre} / \mathrm{Cre}}$; ROSA-YFP ( $\left.\mathrm{Ptfla}{ }^{-/-}\right)$embryos, arguing that in $\mathrm{Ptfla}{ }^{-/-} \mathrm{mu}-$ tants, excessive $\mathrm{Lmxlb}^{+}$neurons originate from Ptflaexpressing progenitors (Fig. $2 \mathrm{~J}, \mathrm{~N}$, arrow, $o, q$, arrowheads). In Ptfla ${ }^{\text {Cre/Cre }}$;ROSA-YFP (Ptfla $\left.{ }^{-/-}\right)$embryos, some Lmxlb ${ }^{+}$/ $\mathrm{YFP}^{+}$cells, in particular those located within a dorsal part of the $\mathrm{YFP}^{+}$domain, coexpressed Phox $2 \mathrm{~b}$, and, therefore, resembled dA3 cells (Fig. $2 N-p^{\prime \prime}$ ). Many other $L m x 1 b^{+} / \mathrm{YFP}^{+}$cells, specifically those located within a ventral part of the $\mathrm{YFP}^{+}$domain, were Phox $2 \mathrm{~b}^{-}$, resembling $\mathrm{dB} 3$ cells (Fig. $2 \mathrm{~N}, q, q^{\prime}$ ).

Previously, it has been shown that the loss of Ptfla does not affect proliferation in the E11.5 rh7 VZ (Yamada et al., 2007). We found that apoptosis was not significantly increased in the $P t f 1 a^{-/-}$rh7 alar plate (Fig. $2 R-T$ ). Therefore, our data argue that in early $P t f 1 a^{-/-}$rh7, rather than producing dA4 and $\mathrm{dB} 1$ neurons, Ptfla-expressing progenitors in the rh7 VZ produce cells molecularly resembling $\mathrm{dA} 3$ and $\mathrm{dB} 3$ neurons. In E11.5 Ptf $1 a^{\text {Cre/Cre }}$;ROSA-YFP mutants, the ectopic Lmx $1 \mathrm{~b}^{+} / \mathrm{Phox} \mathrm{b}^{+} /$ $\mathrm{YPF}^{+}$cells were located adjacent to a dorsal segment of the $\mathrm{Ptfla}^{+} / \mathrm{YFP}^{+} \mathrm{VZ}$ (Fig. $2 N-q^{\prime}$ ), which normally gives rise to dA4 neurons (Fig. 2A, C; Sieber et al., 2007, Storm et al., 2009). Thus, it is likely that in the absence of Ptfla at least some dorsally located Ptfla-expressing VZ progenitors produce dA3-like cells instead of dA4 neurons, while more ventrally located Ptflaexpressing progenitors aberrantly generate $\mathrm{Lmx} 1 \mathrm{~b}^{+} / \mathrm{Phox} 2 \mathrm{~b}^{-}$ dB3-like neurons (summarized in Fig. 2U).

\section{Cell-fate misspecification in early $\mathrm{Ptfla}^{-/-}$rh2-6}

Next, we analyzed rh2-6 at E11.5. In rh4, Lhx1/5 ${ }^{+} \mathrm{dA} 4$ and Lhx $1 / 5^{+} / \mathrm{Pax} 2^{+} \mathrm{dB} 1$ cells, normally arising from Ptf1a-exp-

\section{$\leftarrow$}

(Figure legend continued.) $\quad P t f 1 a^{-1-} \mathrm{rh} 7\left(\boldsymbol{B}\right.$, open arrowhead, $\boldsymbol{D}$, arrowhead) was YFP ${ }^{-}$in Ptf1a ${ }^{\text {Cre/(re, }}$ ROSA-YFP embryos (e, arrowheads), indicating that these cells do not originate from Ptf1a-expressing progenitors and, therefore, are likely ventrally migrated dA2 cells rather than dA4 cells. F, G, In Ptf1 $a^{-/-}$rh7, dA3 neurons expanded ventrally, while dB3 expanded dorsally. $H, I$, Quantification of $\mathrm{dA} 3$ and dB3 cells in $P t f 1 a^{-/}$rh7 revealed a significant increase in the number of dA3 cells $(p=0.0016 ; \boldsymbol{H})$, and dB3 cells $\left(p=8.2 \times 10^{-5} ; \boldsymbol{I}\right)$ in Ptf1a ${ }^{-\prime-}$ embryos relative to control littermates. $J-I^{\prime \prime}$, In Ptf1a $a^{\text {Cre/+}} ;$ ROSA-YFP embryos, virtually all $L m \times 1 b^{+}$ cells, including both $\mathrm{dA} 3$ and $\mathrm{dB} 3$ cells, were YFP ${ }^{-}$, indicating that a majority of these cells do not normally originate from Ptf1a-expressing progenitors $\left(\boldsymbol{J}, \boldsymbol{k}, \boldsymbol{m}\right.$, arrows). Rare $\mathrm{Lmx}_{\mathrm{Tb}}{ }^{+}$/ YFP $^{+}$cells found in Ptf1 $a^{\text {Cre/ }}{ }^{+}$;ROSA-YFP control embryos ( $\boldsymbol{k}$, arrowhead) coexpressed Phox2b $\left(\boldsymbol{I}-\boldsymbol{I}^{\prime \prime}\right)$ and, therefore, were dA3 cells. $\boldsymbol{N}-\boldsymbol{q}^{\prime}, \ln$ Ptf1a ${ }^{\text {Cre/(re, }}$,ROSA-YFP $\left(\right.$ Ptfla $\left.^{-/-}\right)$embryos, many $\mathrm{Lmx}_{1 \mathrm{~b}}{ }^{+}$cells were $\mathrm{YFP}^{+}(\boldsymbol{N}$, arrow, $\boldsymbol{0}, \boldsymbol{q}$, arrowheads), indicating that they originated from Ptf1a-expressing progenitors. Some of these $\mathrm{Lmx}_{1 \mathrm{~b}}{ }^{+} / \mathrm{YFP}{ }^{+}$cells, particularly those located adjacent to a dorsal segment of the YFP ${ }^{+} V Z$, coexpressed Phox $2 b$ ( $\boldsymbol{p}-\boldsymbol{p}^{\prime \prime}$, arrowheads), suggesting that they were $\mathrm{dA} 3$ cells. $\mathrm{Lmx}_{1 \mathrm{~b}}{ }^{+} / \mathrm{YFP}^{+}$cells, located adjacent to a ventral segment of the YFP ${ }^{+}$VZ were Phox2b ${ }^{-}\left(\boldsymbol{q}, \boldsymbol{q}^{\prime}\right)$, adopting an expression profile of dB3 cells. $\boldsymbol{R}-\boldsymbol{T}$, Arrowheads point to Casp $3^{+}$cells. Quantification of apoptotic cells in the rh7 alar plate, where $\mathrm{Ptfla}^{+} \mathrm{VZ}$ progenitors and their newly generated progeny are located, revealed no significant difference between control and Ptf1a ${ }^{-1-}$ embryos (cell counts were normalized to controls; NS, nonsignificant). $\boldsymbol{U}$, Summary of cell-fate misspecification in early $P\left(f 1 a^{-1-} \mathrm{rh} 7\right.$. In the absence of Ptf1a, Ptf1a-expressing progenitors in the VZ rather than producing $\mathrm{dA4}$ and $\mathrm{AB} 1$ neurons, produce $\mathrm{A} A 3$ and $\mathrm{dB} 3$ neurons, which normally arise adjacent to cells belonging to the Ptfla lineage. Scale bars: $A-D, F, G, J, N, \boldsymbol{R}, \mathbf{S}, 100 \mu \mathrm{m} ; \boldsymbol{e}, 40 \mu \mathrm{m} ; \boldsymbol{k}, \boldsymbol{m}, \boldsymbol{0}, \boldsymbol{q}, \boldsymbol{q}^{\prime}, 30 \mu \mathrm{m} ; \boldsymbol{I}^{-\boldsymbol{I}^{\prime \prime}}$, $p-p^{\prime \prime}, 50 \mu \mathrm{m}$. ressing progenitors, did not appear in $\mathrm{Ptfla}^{-/-}$mutants (Fig. $3 A-E)$. Instead, as in Ptfla $a^{-/-} \mathrm{rh} 7$, in $\mathrm{Ptfla}^{-/-} \mathrm{rh} 4, \mathrm{Lmxlb}^{+}$ Phox $2 \mathrm{~b}^{+} \mathrm{dA} 3$ cells expanded ventrally and were increased in number (by $\sim 70 \%$; $p=0.003$; Fig. $3 F-H$ ). Compared with rh7, in rh4-6 of wild-type E11.5 embryos, an additional population, Phox $2 \mathrm{~b}^{+} / \mathrm{Lmx} 1 \mathrm{~b}^{-} \mathrm{dB} 2$ cells, arises between $\mathrm{dB} 1$ and $\mathrm{dB} 3$ neurons (Figs. 1C, 3F; Sieber et al., 2007, 2009). Thus, in wild-type rh4, dB1 cells are ventrally flanked by dB2 rather dB3 cells. Unexpectedly, in $P t f 1 a^{-/-}$rh4, Phox $2 b^{+} \mathrm{dB} 2$ cells did not expand dorsally (Fig. 3F-G). Instead, ectopic dB3-like Lmxlb $^{+}$/ Phox $2 \mathrm{~b}^{-}$cells appeared dorsal to the band of $\mathrm{dB} 2$ cells (Fig. $3 G$, arrow). Analysis of embryos carrying $P t f 1 a^{C r e} / R O S A-Y F P$ fatemapping alleles revealed that in contrast to control rh4, where very few $\mathrm{YFP}^{+} / \mathrm{Lmxlb}^{+}$cells were detected (Fig. 3I-l), in Ptfla $a^{-/-}$rh4, many $\mathrm{YFP}^{+}$cells coexpressed Lmx1b (Fig. 3M, arrow, $n)$. Some of these $\mathrm{Lmx} \mathrm{b}^{+} / \mathrm{YFP}^{+}$cells, in particular those located within a dorsal part of the $\mathrm{YFP}^{+}$domain, coexpressed Phox $2 \mathrm{~b}$, adopting a gene expression profile of dA3 cells (Fig. $3 M$, $n-p$, arrowheads). Other $\mathrm{Lmx}_{\mathrm{b}} \mathrm{b}^{+} / \mathrm{YFP}^{+}$cells were Phox $2 \mathrm{~b}^{-}$, corresponding to ectopic dB3-like cells [Fig. $3 M, n-p$, arrows (summarized in Fig. 3Q)].

In wild-type rh2-3, Lmx $1 \mathrm{~b}^{+} / \mathrm{Phox}_{2} \mathrm{~b}^{+} \mathrm{dA} 3$ cells are not produced (Figs. 1B, 4F; Sieber et al., 2007; Storm et al., 2009). In the absence of Ptf1a, in rh2, Ptf1a-expressing cells switched from producing $\mathrm{dA} 4$ and $\mathrm{dB} 1$ cells to generating $\mathrm{Lmx} 1 \mathrm{~b}^{+} / \mathrm{Phox}_{2} \mathrm{~b}^{-}$ (dB3-like) neurons (Fig. 4). Therefore, similar to rh7, in the absence of Ptf1a, during early (E10.5-E11.5) neurogenesis, Ptf1aexpressing progenitors in both $\mathrm{rh} 4-6$ and $\mathrm{rh} 2-3$ produce $\mathrm{Lmx}_{1} \mathrm{~b}^{+}$neurons (either Lmx1b ${ }^{+} / \mathrm{Phox}_{2} \mathrm{~b}^{+} \mathrm{dA} 3$-like neurons or $\operatorname{Lmx} 1 \mathrm{~b}^{+} / \mathrm{Phox} 2 \mathrm{~b}^{-}$neurons) rather than $\mathrm{dA} 4 / \mathrm{dB} 1$ neurons (summarized in Fig. 5).

\section{During late neurogenesis, in Ptfla ${ }^{-/-}$rh7, Ptfla-expressing progenitors excessively produce $\mathrm{dBLb}$ neurons at the expense of dBLa neurons}

In contrast to $\mathrm{rh} 2-6$, where $\mathrm{dA} / \mathrm{dB}$ neurons arise throughout neurogenesis, after E12, Pax ${ }^{+} \mathrm{dBLa}$ and $\mathrm{Lmx} 1 \mathrm{~b}^{+} \mathrm{dBLb}$ neurons arise in a salt-and-pepper pattern from a broad dorsal segment of the wild-type rh7 VZ (Figs. 1E, 6E-i'; Sieber et al., 2007). Because the pattern of neuronal formation in late (after E12) rh7 is clearly different from that in early (E10.5-E11.5) rh7 as well as early and late rh2-6, we specifically investigated the role of Ptfla during late rh7 neurogenesis.

We found that in control E12.5 rh7, Ptf1a is specifically expressed in a dorsal segment of the VZ, which, as expected, was $\mathrm{YFP}^{+}$in $\mathrm{Ptfla} \mathrm{Cre/+}^{\mathrm{C}}$;ROSA-YFP embryos (or $\beta$-gal ${ }^{+}$in $P t f 1 a^{C r e /+} ; R O S A-L a c Z$ embryos; Fig. $6 A-C$, bracket). The Ptfla-expressing VZ was located directly adjacent to a more lateral area populated by Pax $2^{+} \mathrm{dBLa}$ and $\mathrm{Lmx} 1 \mathrm{~b}^{+} \mathrm{dBLb}$ neurons (Fig. 6C,E, $G, i, i^{\prime}$ ). Surprisingly, both Pax $2^{+} \mathrm{dBLa}$ and $\mathrm{Lmxlb}^{+} \mathrm{dBLb}$ neurons were $\beta$-gal ${ }^{+}$in E12.5 Ptfla ${ }^{\mathrm{Cre} /+}$; ROSA-LacZ rh7 (Fig. 6R,S), although in early rh7 (Fig. $2 A, C, J$ ) as well as in the spinal cord (Glasgow et al., 2005; Hori et al., 2008; Borromeo et al., 2014) and cerebellum (Millen et al., 2014) Ptf1a-expressing progenitors produce Pax $2^{+}$neurons but are not a significant source of $\mathrm{Lmx}_{\mathrm{Bb}}{ }^{+}$neurons. In Ptf $1 a^{-1-}$ rh7, Pax ${ }^{+}$dBLa neurons were absent, while dBLb neurons significantly increased in number $(\sim 1$. 8 -fold compared with controls, $p=0.0011$; Fig. $6 E-K)$. Similar to control littermates, in rh7 of Ptf $1 a^{\mathrm{Cre} / \mathrm{Cre}} ;$ ROSA-LacZ embryos, Lmx1b $\mathrm{dBLb}$ neurons were $\beta$-gal ${ }^{+}$(data not shown), indicating that in Ptfla $a^{-/-}$mutants, excessive dBLb neurons originate from Ptfla-expressing progenitors. 

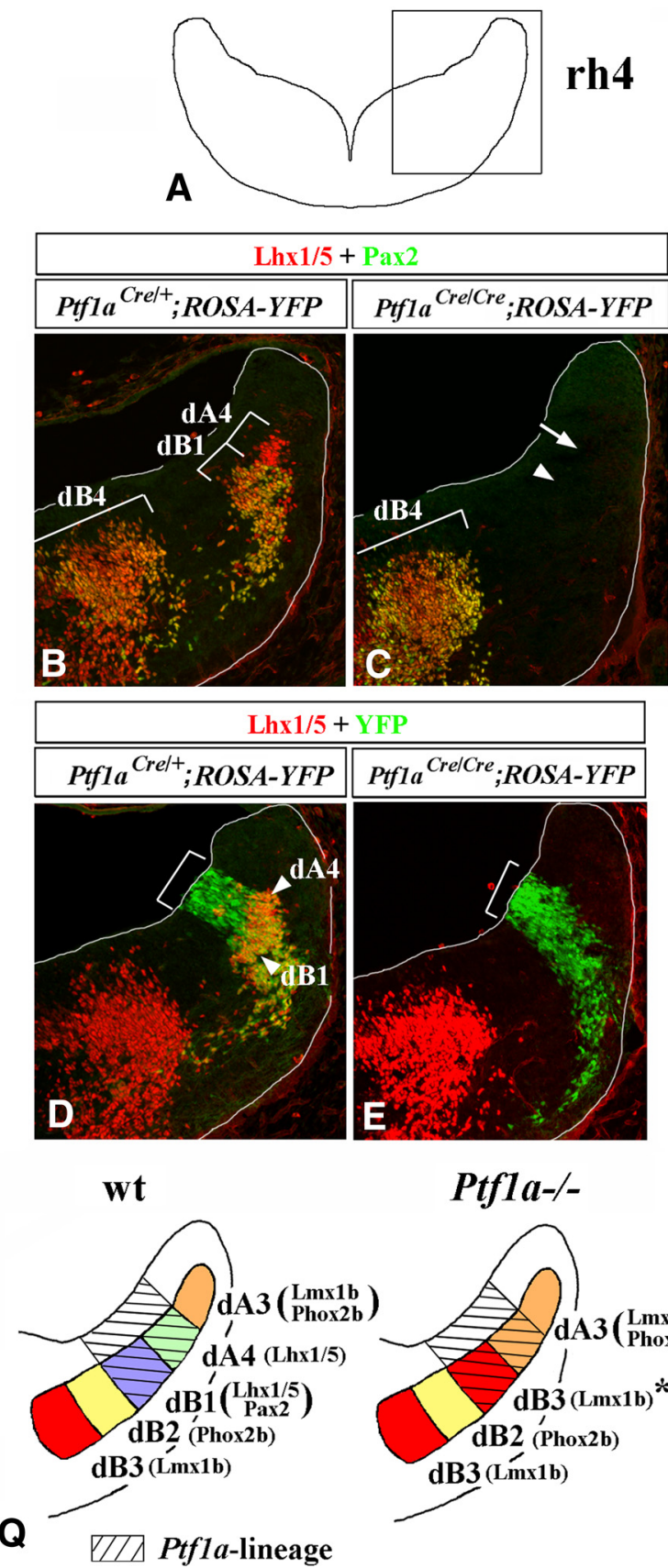
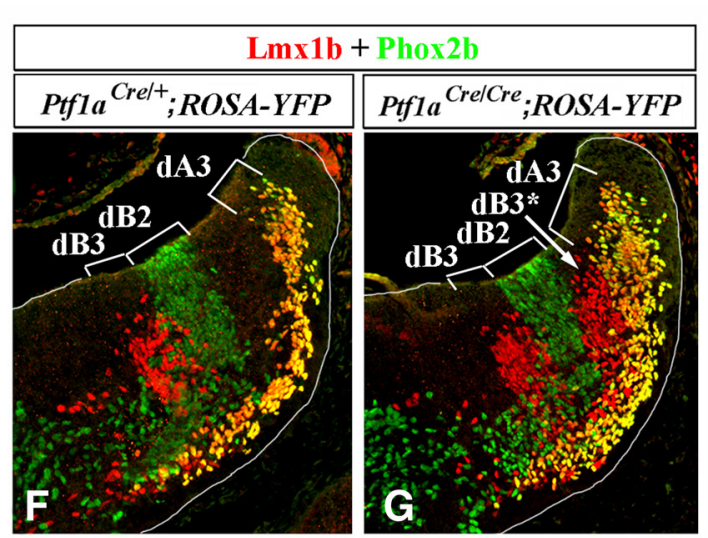

dA3 cells, fold change
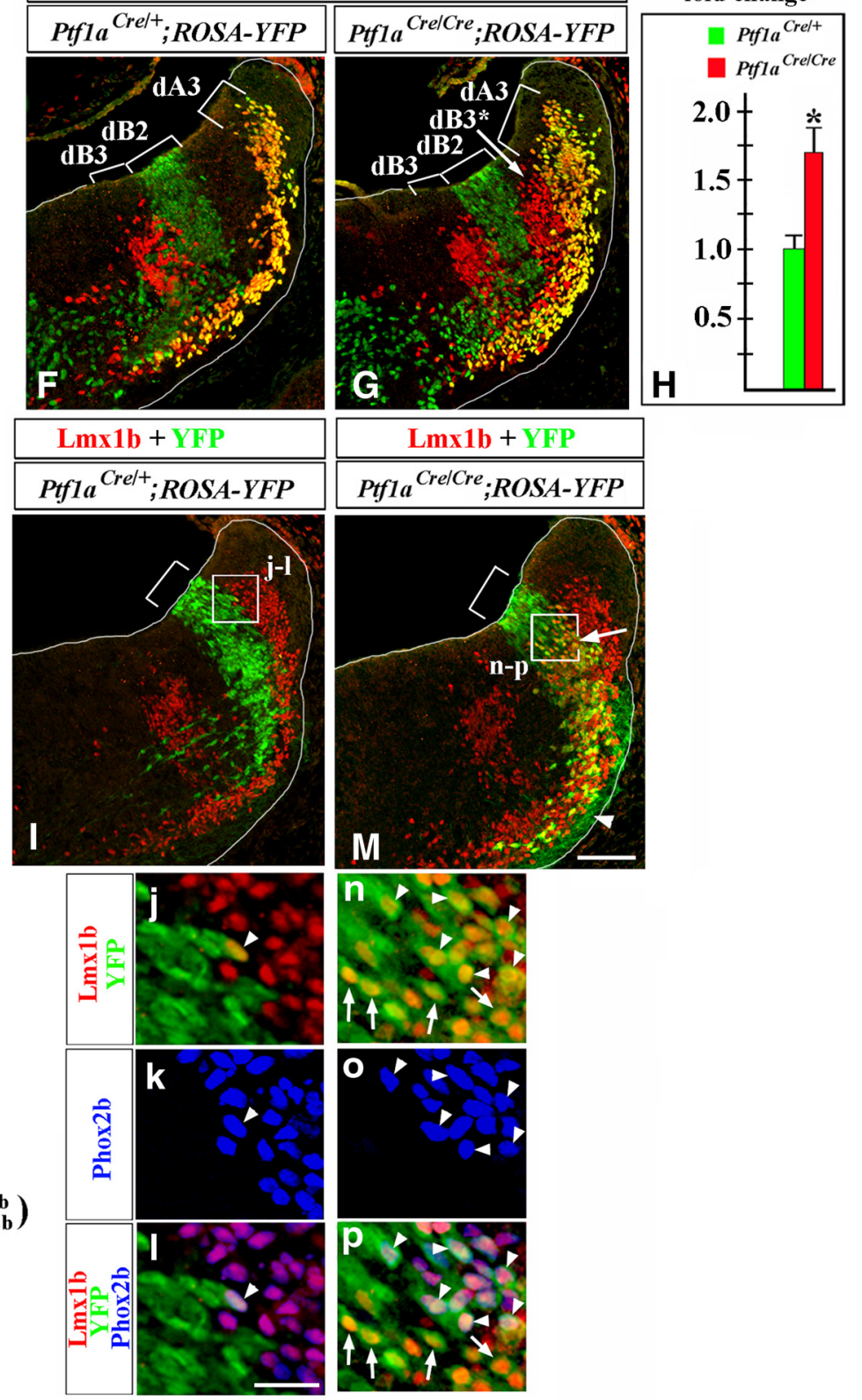

Figure 3. Similar to $\mathrm{rh} 7$, in E11.5 Ptf1a ${ }^{-/-}$rh4, early-born $\mathrm{dA} 4$ and $\mathrm{dB} 1$ neurons transfate to $\mathrm{dA} 3$ and $\mathrm{dB} 3$ neurons. Transverse sections of $\mathrm{E} 11.5$ hindbrain taken at the level of rh4 with genotypes and antibody markers indicated. $\boldsymbol{B}-\boldsymbol{G}, \boldsymbol{I}$, and $\boldsymbol{M}$ correspond to the region boxed in rh4 schematic in $\boldsymbol{A}$. Brackets in $\boldsymbol{B}, \boldsymbol{C}, \boldsymbol{F}$, and $\boldsymbol{G}$ indicate the positions along the dorsal-ventral axis at which specific neuronal populations emerge. Brackets in $\boldsymbol{D}, \boldsymbol{E}, \boldsymbol{I}$, and $\boldsymbol{M}$ indicate the dorsal-ventral extent of YFP expression in the VZ, which was not dramatically different between

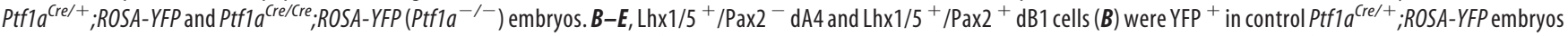
(D), and, therefore, originate from Ptf1a-expressing progenitors. $\boldsymbol{C}$, In Ptf1a ${ }^{-/-}$rh4, neither dA4 (arrow) nor dB1 (arrowhead) are present. $\boldsymbol{F}-\boldsymbol{H}$, In $P t f 1 a^{-/-}$rh4, dA3 neurons expanded ventrally. Quantification of dA3 cells in Ptf1a ${ }^{-1-}$ rh4 revealed a significant increase in the number of dA3 cells relative to control littermates $(p=0.003 ; \boldsymbol{H})$. dB2 cells did not expand dorsally. Instead, in Ptf1a ${ }^{-1-}$ rh4, dB3-like Lmx1b ${ }^{+}$cells appeared at ectopic positions dorsal to dB2 domain (labeled as dB3* in G). I-p, rh4 of control and Ptf1a ${ }^{-/-}$embryos carrying Ptf1a-Cre/ROSA-YFP fate-mapping alleles. High-magnification insets $\left(\boldsymbol{j}-\boldsymbol{I}\right.$ and $\boldsymbol{n}-\boldsymbol{p}$ ) correspond to regions boxed in $\boldsymbol{I}$ and $\boldsymbol{M}$. $\boldsymbol{I} \boldsymbol{I} \boldsymbol{I}, \boldsymbol{I n} P$ Ptf1a ${ }^{\text {Crel+}+} ;$;ROSA-YFP (control) embryos, virtually all $\mathrm{Lmx}_{1 \mathrm{~b}}{ }^{+}$cells, including both $\mathrm{dA} 3$ and $\mathrm{dB} 3$ cells were YFP ${ }^{-}$, indicating that the majority of these cells do not normally originate from Ptf1a-expressing progenitors. $j-I$, Rare

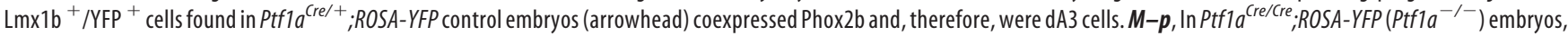
many $\mathrm{Lmx}_{1 \mathrm{~b}}{ }^{+}$cells were YFP ${ }^{+}\left(\boldsymbol{M}\right.$, arrow, $\boldsymbol{n}-\boldsymbol{p}$, arrowheads and arrows), indicating that they originated from Ptf1a-expressing progenitors. Some of these $\mathrm{Lmx} 1 \mathrm{~b}^{+} / \mathrm{YFP}^{+}$ cells, particularly those located adjacent to a dorsal segment of the YFP ${ }^{+}$VZ, coexpressed Phox2b ( $\boldsymbol{n}-\boldsymbol{p}$, arrowheads), suggesting that they adopted the fate of dA3 cells. Lmx $1 b^{+} /{ }^{+}$YFP ${ }^{+}$ cells, located adjacent to a ventral segment of the YFP ${ }^{+} \mathrm{VZ}$, were Phox $2 \mathrm{~b}^{-}(\boldsymbol{n}-\boldsymbol{p})$, adopting an expression profile of dB3 cells. While in Ptf1a ${ }^{\text {(re//re }} ; R^{2}$ OSA-YFP (Ptf1a $\left.{ }^{-/-}\right)$mutants, the majority of YFP ${ }^{+}$cells were clearly $\mathrm{Lmx}_{1 b^{+}}{ }^{+}$, some YFP ${ }^{+}$cells appeared $\mathrm{Lmx}_{1 \mathrm{~b}}{ }^{-}$(M, arrowhead). The identity of these YFP ${ }^{+} / \mathrm{Lmx} 1 \mathrm{~b}^{-}$cells is unknown. $\boldsymbol{Q}$, Summary of cell-fate misspecification in early Ptf1a ${ }^{-1-}$ rh4. In the absence of Ptf1a, Ptf1a-expressing progenitors in the VZ rather than producing $\mathrm{dA} 4$ and dB1 neurons, produce $\mathrm{dA3}$ - and dB3-like neurons. Scale bars: $\boldsymbol{B}-\mathbf{G}, \boldsymbol{I}, \boldsymbol{M}, 100 \mu \mathrm{m} ; \boldsymbol{j}-\boldsymbol{p}, 25 \mu \mathrm{m}$. 

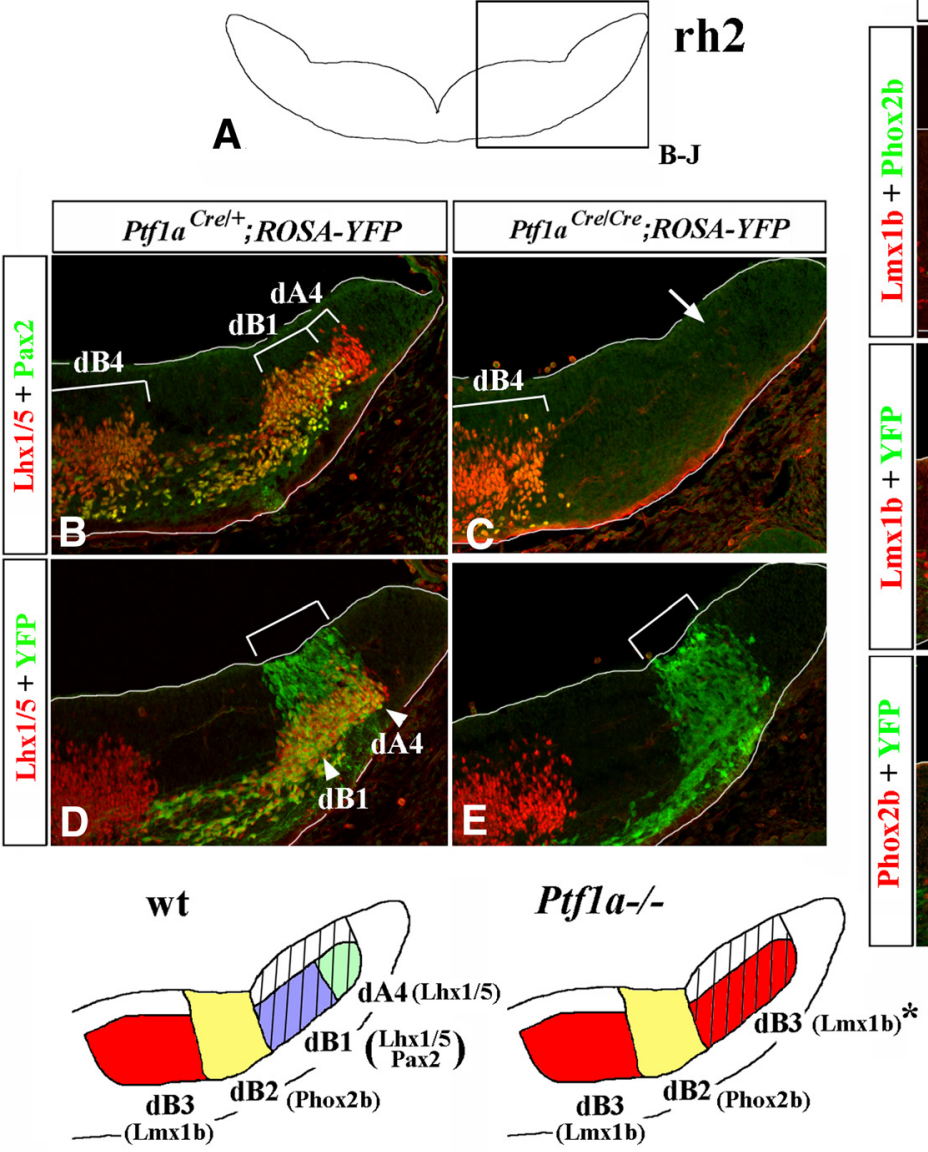
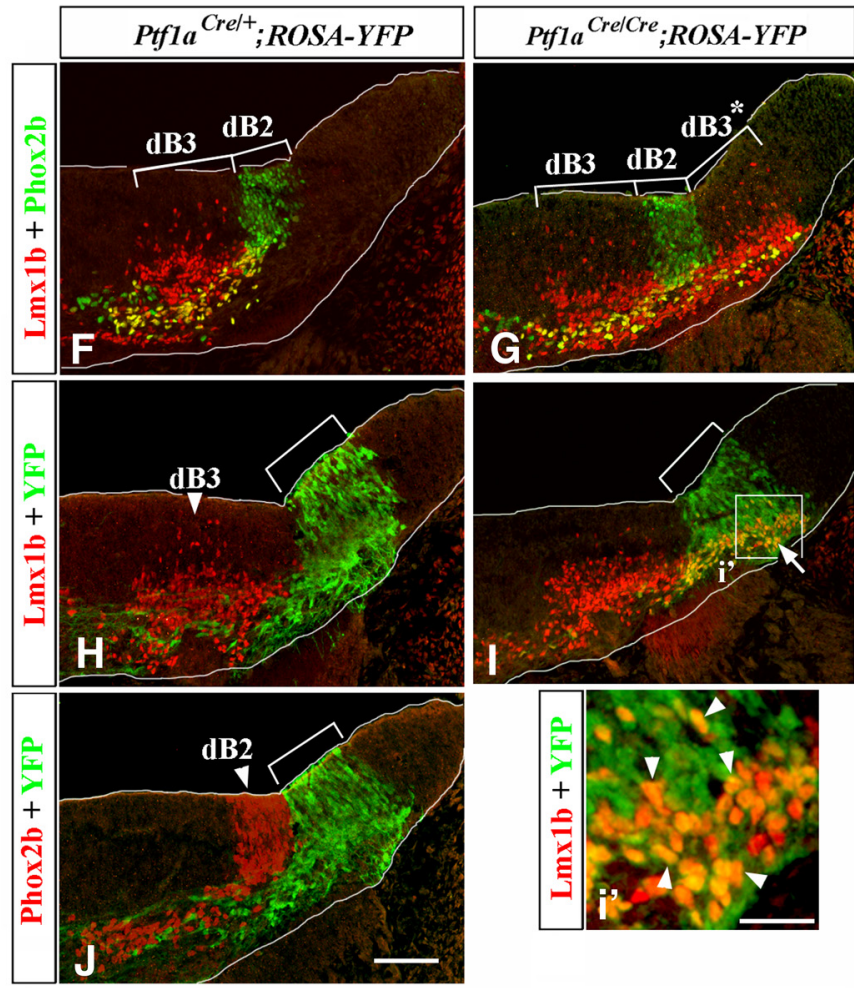

\section{K IIT Ptfla-lineage}

Figure 4. In E11.5 Ptf1a ${ }^{-/-}$rh2, early-born dA4 and dB1 neurons transfate to dB3 neurons. Transverse sections of E11.5 hindbrain taken at the level of rh2, with genotypes and antibody markers indicated. $\boldsymbol{B}-\boldsymbol{J}$, The region boxed in rh2 schematic in $\boldsymbol{A}$. Brackets in $\boldsymbol{B}, \boldsymbol{C}, \boldsymbol{F}$, and $\boldsymbol{G}$ indicate the positions along the dorsal-ventral axis at which specific neuronal populations emerge. Brackets in $\boldsymbol{D}, \boldsymbol{E}, \boldsymbol{H}, \boldsymbol{I}$, and $\boldsymbol{J}$ indicate dorsal-ventral extent of YFP expression in the VZ, which was not significantly different between Ptf1a ${ }^{\text {Cre/ }} ;$; ROSA-YFP and

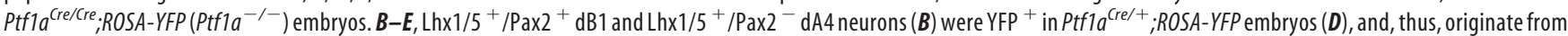
Ptf1a-expressing progenitors. In Ptf1a ${ }^{-/-}$rh2, neither dA4 nor dB1 are present ( $\boldsymbol{C}$, arrow, $\left.\boldsymbol{E}\right) . \boldsymbol{F}, \boldsymbol{G}, \operatorname{In} P t f 1 a^{-/-}$rh2, dB2 cells did not expand dorsally. Instead, dB3-like $\mathrm{Lmx} \mathbf{1 b}{ }^{+}$cells appeared at ectopic positions dorsal to dB2 domain (labeled as dB3* in G). $\boldsymbol{H}-\boldsymbol{J}$, In control Ptf1a ${ }^{\text {Cre/+}} ;$;ROSA-YFP rh2, Ptf1a-expressing progenitors are not a significant source of either $\mathrm{Lmx1b}^{+} \mathrm{dB3}(\boldsymbol{H})$ or Phox2b ${ }^{+} \mathrm{dB2}(\boldsymbol{J})$ neurons. In Ptf1a ${ }^{\text {Cre/(re }}$;ROSA-YFP $\left(\right.$ Ptf1a $\left.{ }^{-/-}\right)$rh2, ectopic Lmx1b ${ }^{+}$dB3-like cells were YFP ${ }^{+}\left(\boldsymbol{I}\right.$, arrow, $\boldsymbol{i}^{\prime}$, arrowheads), indicating that they originate from Ptf1a-expressing progenitors. $\boldsymbol{K}$, Summary of cell-fate misspecification in early Ptf1a ${ }^{-/}$rh2. In the absence of Ptf1a, Ptf1a-expressing progenitors do not produce dA4 and dB1 neurons. Rather than transfating to adjacent dB2 neurons, cells belonging to the Ptf1a lineage initiate the expression of $L m \times 1 b$, a marker of $d B 3$ neurons. Scale bars: $\boldsymbol{B}-\boldsymbol{J}$, 100 $\mu \mathrm{m} ; \boldsymbol{j}^{\prime}, 25 \mu \mathrm{m}$.

\section{early (e10.5-e11.5)}

wt

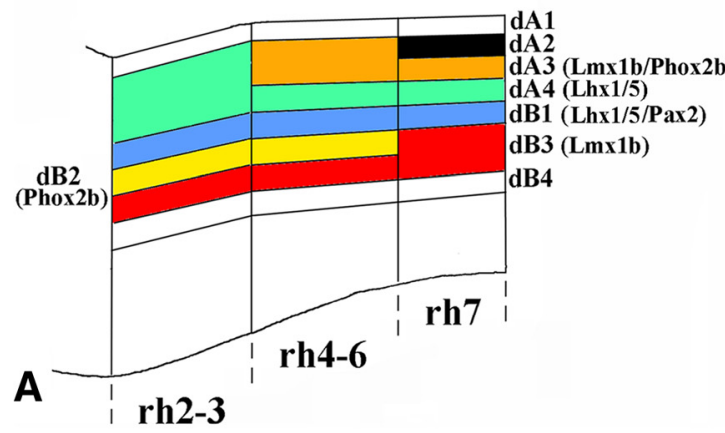

Ptfla-/-

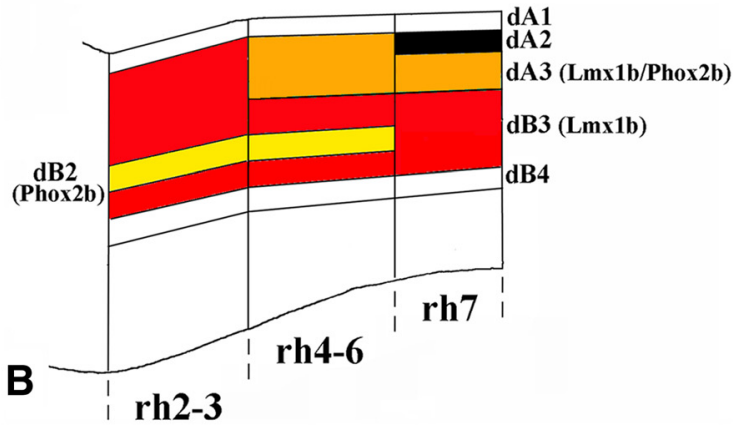

Figure 5. Summary of neuronal subtypes in wild-type and $P t f 1 a^{-/-}$rh2-7 at E11.5. $\boldsymbol{A}, \boldsymbol{B}$, Side view of E11.5 wild-type $(\boldsymbol{A})$ and $P t f 1 a^{-/-}(\boldsymbol{B})$ hindbrain with $\mathrm{dA}$ and dB neuronal populations extending through rhombomeres. In Ptf1a ${ }^{-/-}$mutants, dA4 and dB1 neurons are not generated through rh2-7, and, depending on the anterior-posterior level, their positions are occupied by excessive $\mathrm{dA} 3$ and/or $\mathrm{dB} 3$ neurons. 

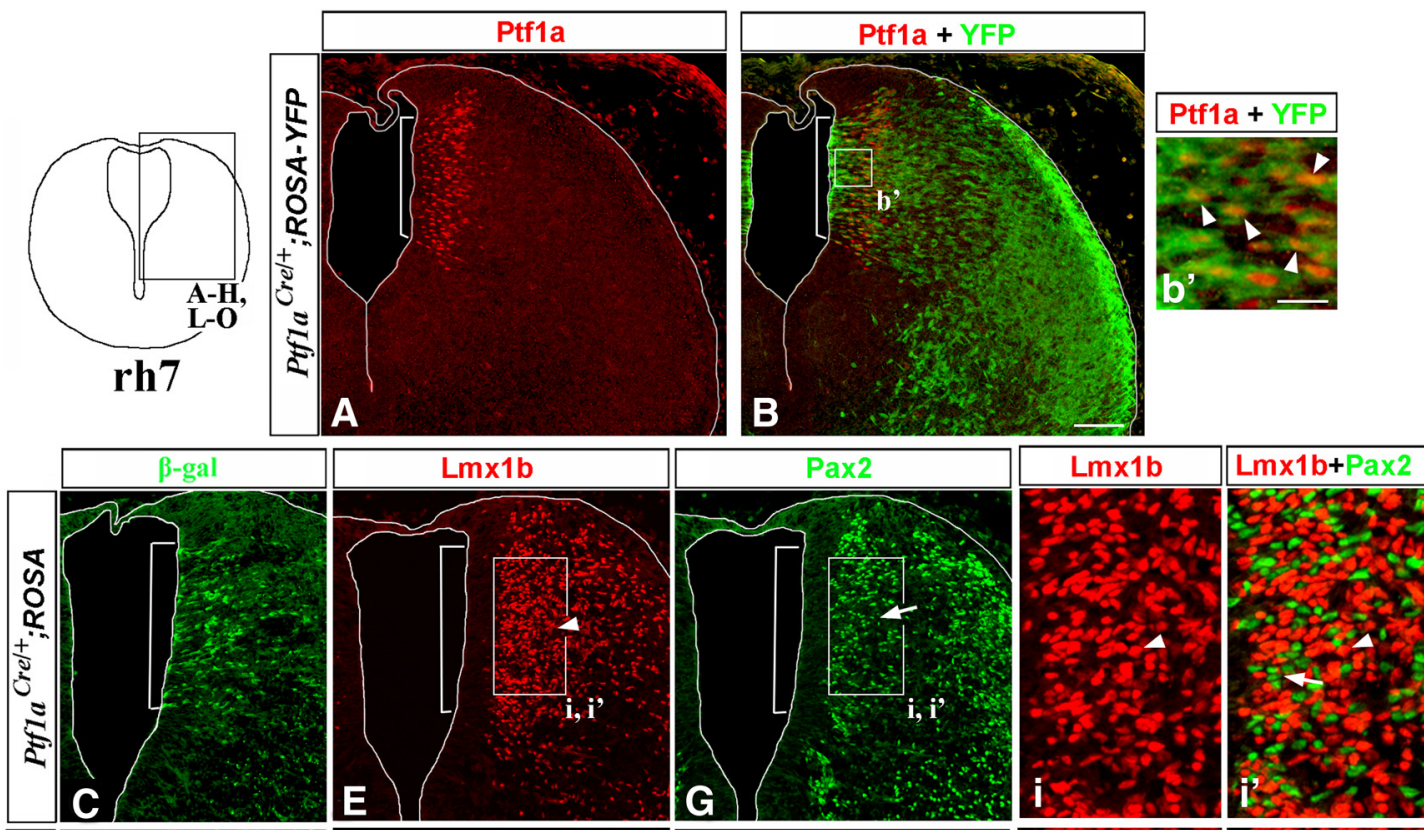

Lmx1b+ dBLb

cells, fold change
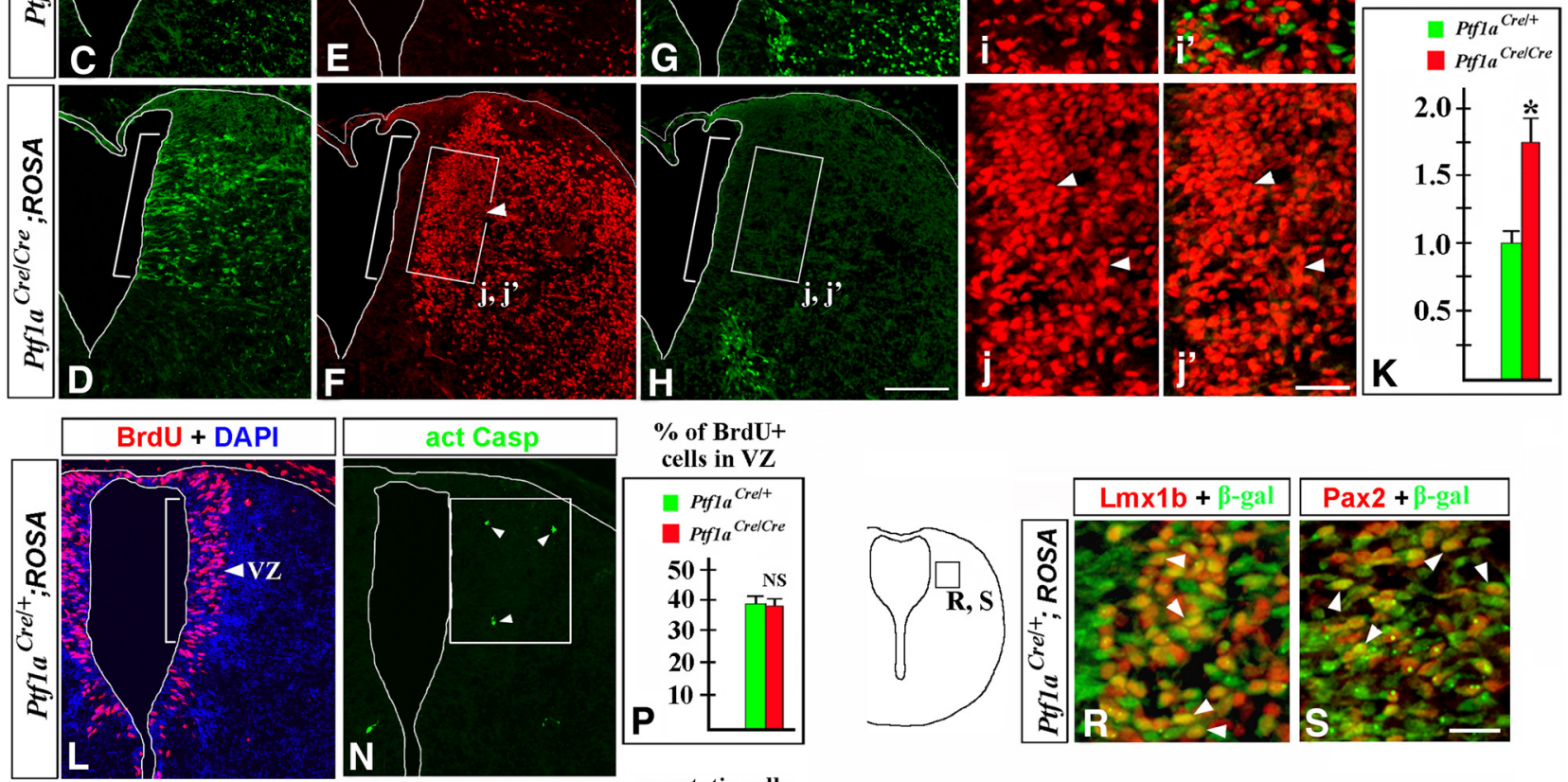

$\%$ of BrdU+

cells in VZ
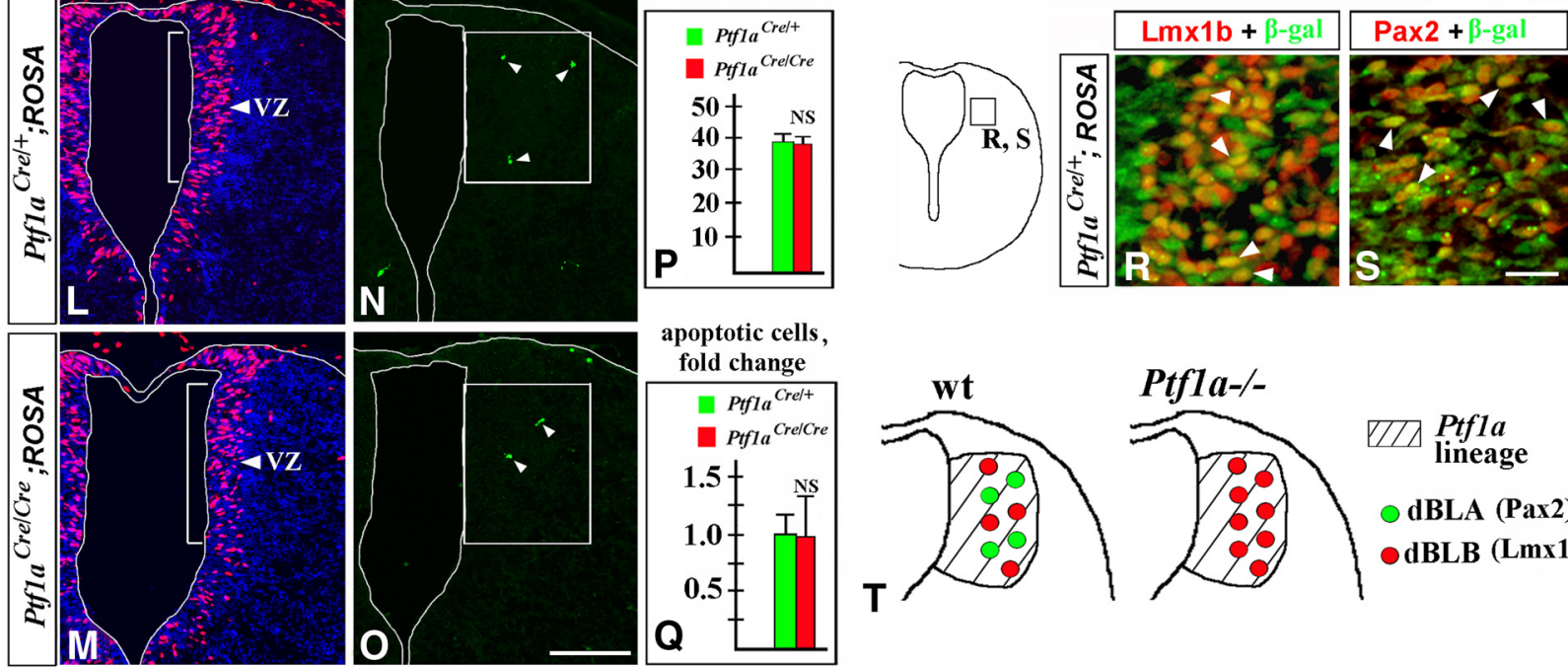

apoptotic cells,

fold change
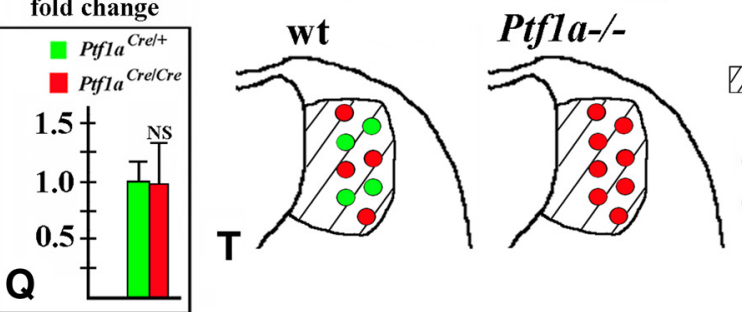

Ptf1a

lineage

dBLA (Pax2)

dBLB (Lmx1b)

Figure 6. In the absence of Ptf1a, excessive late-born $L \mathrm{Lx} 1 \mathrm{~b}^{+} \mathrm{dBLb}$ neurons are produced in $\mathrm{E} 12.5 \mathrm{rh} 7$ instead of Pax2 ${ }^{+} \mathrm{dBL}$ neurons. Transverse sections of E12.5 rh7 with genotypes and antibody markers indicated. Low-magnification panels correspond to the region boxed in the rh7 schematic in the top left corner. High-magnification panels correspond to regions boxed in related data panels. $\boldsymbol{A}-\boldsymbol{b}^{\prime}$, In wild-type E12.5 rh7, Ptf1a is specifically expressed in the dorsal VZ (A, $\boldsymbol{B}$, bracket), and Ptf1a-expressing cells ( $\boldsymbol{b}^{\prime}$, arrowheads) and their progeny are labeled by YFP expression

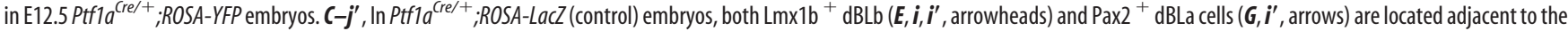

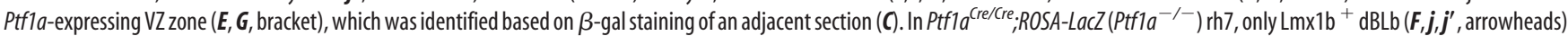
but not Pax2 ${ }^{+} \mathrm{dBLa}\left(\boldsymbol{H}, \boldsymbol{j}^{\prime}\right)$ were found. Cell counts in a 100- $\mu \mathrm{m}$-wide box located adjacent to the Ptf1a-expressing VZ (the region boxed in $\boldsymbol{E}-\boldsymbol{H}$ ) revealed a 1.8 -fold increase in the number of $\mathrm{Lmx1b}^{+}$dBLb cells in Ptf1a ${ }^{-1-}$ embryos compared with controls $(p=0.0011) . L, M, P$, Analysis of proliferation in the Ptf1a-expressing VZ (labeled by bracket and identified based on $\beta$-gal staining of an adjacent section). Mice were injected with BrdU and killed $1 \mathrm{~h}$ after the BrdU pulse. Approximately the same fraction of cells was BrdU ${ }^{+}$in the Ptfla-epressing VZ in control and Ptf1a ${ }^{-/-}$embryos [ $\boldsymbol{P}$ value is nonsignificant (NS)]. $\mathbf{N}, \mathbf{O}, \mathbf{Q}$, The number of apoptotic cells was not increased in a $150-\mu \mathrm{m}$-wide domain, containing Ptf1a-expressing progenitors and newly

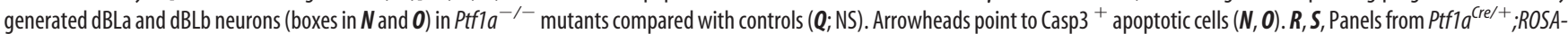
LacZ (control) embryos corresponding to the region boxed in adjacent rh7 schematic. $\boldsymbol{R}, \boldsymbol{S}$, Both $\operatorname{Lmx} 1 \mathrm{~b}^{+} \mathrm{dBLb}\left(\boldsymbol{R}\right.$, arrowheads) and Pax2 ${ }^{+} \mathrm{dBLa} \mathrm{P}\left(\boldsymbol{S}\right.$, arowheads) were $\beta$-gal ${ }^{+}$and, therefore, originate from Ptf1a-expressing progenitors. $\boldsymbol{T}$, Summary of late-born neurons in rh7 of $P t f 1 a^{-1-}$ embryos. Rather than producing dBLa and dBLb neurons, in the absence of Ptf1a, Ptf1a-expressing progenitors produce supernumerary dBLb neurons. Scale bars: $\boldsymbol{A}-\boldsymbol{H}, \boldsymbol{L}-\mathbf{O}, 100 \mu \mathrm{m} ; \boldsymbol{b}^{\prime}, 15 \mu \mathrm{m} ; \boldsymbol{i}-\boldsymbol{j}^{\prime}, 30 \mu \mathrm{m} ; \boldsymbol{R}, \mathbf{S}, 20 \mu \mathrm{m}$. 

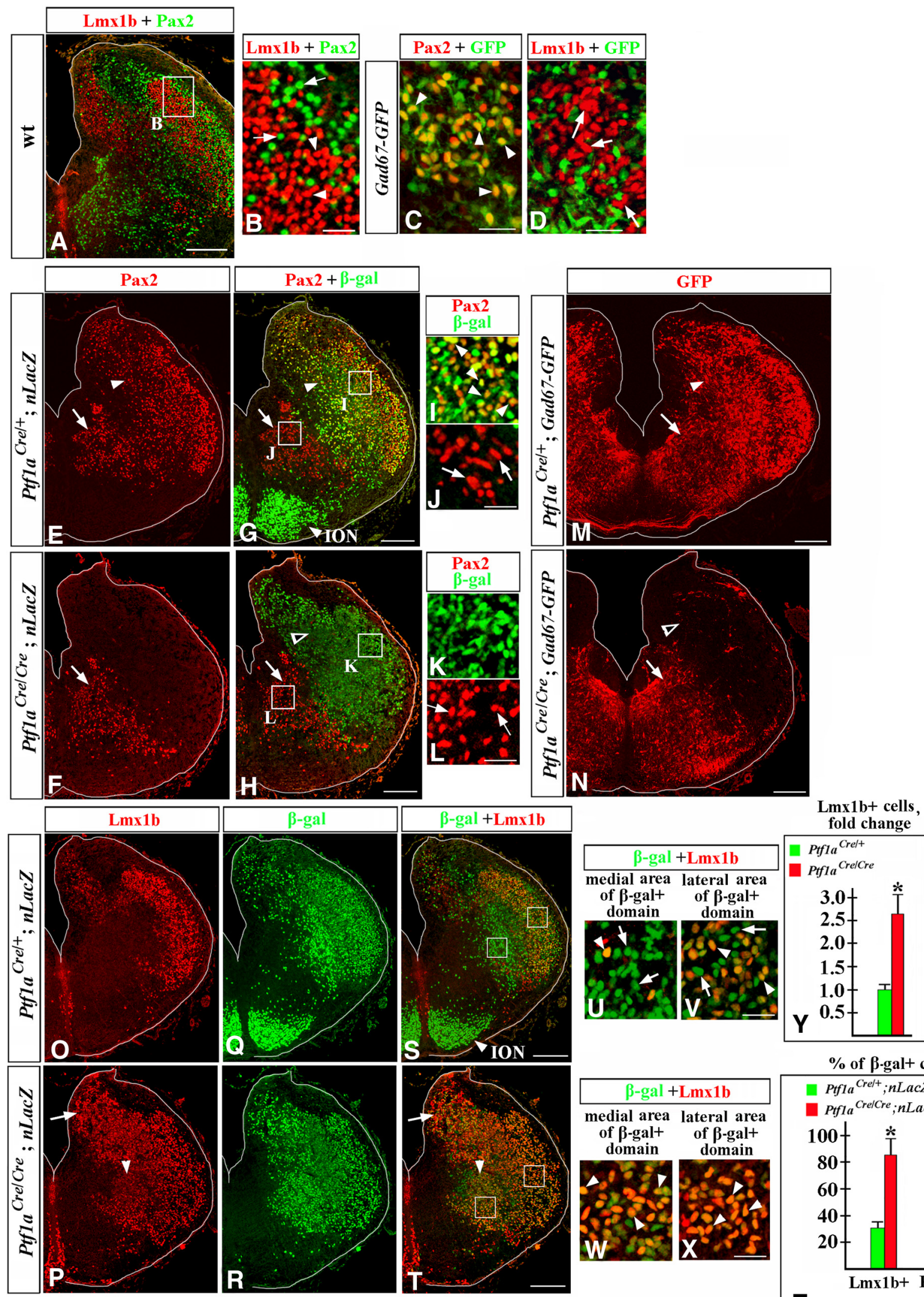

$\%$ of $\beta$-gal+ cells that are

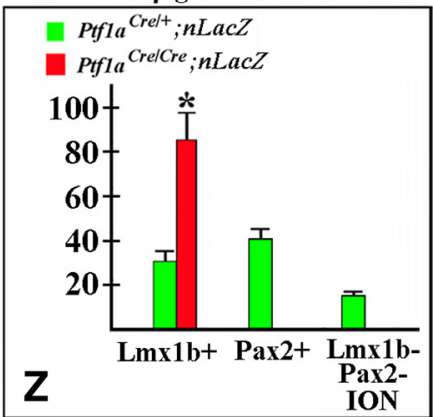

Figure 7. Misspecified neurons in E14.5 Ptf1a ${ }^{-1-}$ rh7. Transverse sections of E14.5 rh7 with genotypes and antibody markers indicated. $A-D, L m \times 1 b$ and Pax2 are expressed in different sets of cells. $\boldsymbol{B}-\boldsymbol{D}$ show higher magnification of cells located in dorsolateral rh7 (e.g., area indicated by a box in a lower-magnification panel, $\boldsymbol{A}$ ). $\boldsymbol{B}$, Arrowheads point to $\mathrm{Lmx} 1 \mathrm{~b}^{+}{ }^{+}$cells, arrows point to

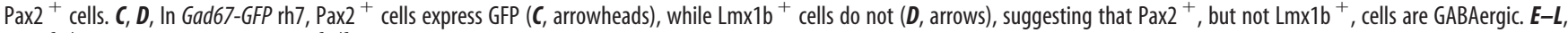

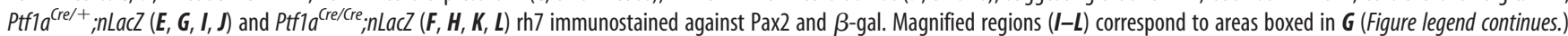


Analysis of proliferation in dorsal rh7 VZ with a $1 \mathrm{~h} \mathrm{BrdU}$ pulse did not reveal a difference between control and $P t f 1 a^{-/-}$ littermates at E12.5 (Fig. $6 L, M, P$ ). Similarly, comparable number of Casp $3^{+}$apoptotic cells were detected within a domain populated by $P t f l a$-expressing progenitors and newly generated $\mathrm{dBLa} / \mathrm{dBLb}$ neurons in E12.5 $\mathrm{Ptfla}^{-/-}$and control littermates (Fig. 6N,O,Q). Together, our data suggest that although in E12.5 rh7 dBLa and dBLb neurons are generated from Ptfla-expressing progenitors, in the absence of Ptfla these progenitors produce excessive Lmx1b ${ }^{+} \mathrm{dBLb}$ neurons at the expense of Pax2 ${ }^{+} \mathrm{dBLa}$ neurons (summarized in Fig. 6T).

\section{In contrast with control embryos, in E14.5 $\mathrm{Ptfl} \mathrm{a}^{-/-} \mathrm{rh} 7$, most cells derived from $P t f 1 a$-expressing progenitors express Lmx1b}

Since we observed a dramatic cell-fate misspecification in the caudal hindbrain of Ptfla mutants during both early and late waves of neurogenesis, we evaluated cellular composition of their rh7 at E14.5, when neurogenesis is essentially complete. Similar to earlier stages, in wild-type E14.5 rh7, Pax2 and Lmx1b continue labeling distinct sets of cells (Fig. $7 A, B$ ). In the cerebellum, spinal cord, and other regions of the CNS, Pax2 is expressed in a subset of GABAergic inhibitory neurons, while Lmxlb is expressed in excitatory neurons (Maricich and Herrup, 1999; Cheng et al., 2004; Glasgow et al., 2005; Dai et al., 2008; Xiang et al., 2012). To label GABAergic neurons, we used Gad67-GFP mice (Chattopadhyaya et al., 2004), in which GFP expression is driven by the regulatory elements of the Gad67 (also known as Gad1) gene (Rasmussen et al., 2007). Gad67, a key enzyme for GABA synthesis, is a marker of GABAergic cells (Cheng et al., 2004; Glasgow et al., 2005; Storm et al., 2009), and GFP expression in Gad67-GFP mice reliably labels many types of GABAergic neurons, including those in the developing hindbrain (Schubert et al., 2010; Waite et al., 2012; Gray, 2013). In E14.5 Gad67-GFP embryos, Pax ${ }^{+}$neurons coexpressed GFP, while $\mathrm{Lmx} 1 \mathrm{~b}^{+}$neurons did not (Fig. $7 C, D$ ), arguing that, similar to other CNS re-

(Figure legend continued.) and $\boldsymbol{H} . \boldsymbol{E}, \mathbf{G}, \boldsymbol{I}, \mathbf{J}$, In wild-type rh7, Pax2 ${ }^{+}$dorsolateral cells are $\beta$-gal ${ }^{+}(\boldsymbol{E}, \boldsymbol{G}, \boldsymbol{I}$, arrowheads $)$ and thus, originate from Ptf1a-expressing progenitors. Pax2 ${ }^{+}$ ventromedial cells are $\beta$-gal- $(\boldsymbol{E}, \boldsymbol{G}, \boldsymbol{J}$, arrows) and originate from progenitors that do not express Ptf1a. F, $\boldsymbol{H}, \boldsymbol{K}, \boldsymbol{L}$, In Ptf1a $a^{\text {Cre/(re }}$, inLacZ (Ptf1a ${ }^{-/-}$) embryos, $\beta$-gal ${ }^{+}$cells, populating dorsolateral rh7, do not express Pax2 $(\boldsymbol{F}, \boldsymbol{H}$, open arrowhead, $\boldsymbol{K})$, while the ventromedial group of Pax ${ }^{+}$cells is not affected $\left(\boldsymbol{F}, \boldsymbol{H}, \boldsymbol{L}\right.$, arrows). $\boldsymbol{M}, \boldsymbol{N}, \operatorname{In}$ Ptf1a ${ }^{-1-}$ Gad67-GFP mutants, GFP staining is lost in dorsolateral ( $\boldsymbol{N}$, open arrowhead) but is preserved in ventromedial (arrow) rh7. 0-X, Low $(\mathbf{0}-\boldsymbol{T})$ and high $(\boldsymbol{U}-\boldsymbol{X})$ magnification of Ptf1a ${ }^{\text {(re/ }} ;$; L LacZ $(\mathbf{O}, \boldsymbol{Q}, \mathbf{S}, \boldsymbol{U}, \boldsymbol{V})$ and $P t f 1 a^{\text {Cre/cre }} ; n L a c Z(P, R, T, W, X)$ rh7 immunostained against $L m x 1 b$ and $\beta$-gal. $\boldsymbol{U}$ and $\boldsymbol{W}$ show cells located in ventromedial rh7 (such as area indicated by left box in $\boldsymbol{S}$ and $\boldsymbol{T}$ ). $\boldsymbol{V}$ and $\boldsymbol{X}$ show cells located in dorsolateral rh7 (such as area indicated by right box in $S$ and $T$ ). $\mathbf{0}-Z, \operatorname{In} P t f 1 a^{\text {Gre/ }}$ ${ }_{+}^{+}$; $n$ LacZ control embryos, a fraction of $\beta$-gal ${ }^{+}$cells (arrowheads) coexpress $\operatorname{Lmx} 1 \mathrm{~b}(\mathbf{O}, \mathbf{Q}, \mathbf{S}$, yellow cells). Approximately a half of $\beta$-gal ${ }^{+}$cells were $\mathrm{Lmx} 1 \mathrm{~b}^{+}$in lateral $\mathrm{rh} 7(\boldsymbol{V}$, arrowheads), while in more medial $\mathrm{rh} 7$, virtually all $\beta$-gal ${ }^{+}$cells were $\mathrm{Lmx}_{1 \mathrm{~b}}{ }^{-}$(U, arrows). In Ptf1a ${ }^{\text {Cre/(re },}, n L a c Z\left(P t f 1 a^{-1-}\right)$ embryos, a vast majority of $\beta$-gal ${ }^{+}$cells coexpress $\operatorname{Lmx} 1 \mathrm{~b}(\boldsymbol{P}, \boldsymbol{R}$, $T$ ), including those populating both medial and lateral $\operatorname{rh} 7(\boldsymbol{W}, X$, arrowheads). $Y$, Cell counts revealed a dramatic increase in the number of $\mathrm{Lmx} 1 \mathrm{~b}^{+}$cells in E14.5 Ptf1a ${ }^{-/-}$rh7 compared with control littermates $(p=0.006)$. Excessive $\mathrm{Lmx}_{1 \mathrm{~b}}{ }^{+}$cells were particularly obvious in dorsomedial $(\boldsymbol{P}, \boldsymbol{T}$, arrow) and ventromedial $(\boldsymbol{P}, \boldsymbol{T}$, arrowhead) areas of rh7. $\boldsymbol{Z}$, Quantification of the fractions of $\beta$-gal ${ }^{+}$cells expressing specific markers in $P$ tffa ${ }^{-/-}$and control littermates. Approximately $85 \%$ of $\beta$-gal ${ }^{+}$cells coexpressed Lmx1b in Ptf1a ${ }^{\text {Cre/(ree/; }}$ L LacZ (Ptf1a ${ }^{-1-}$ ) rh7 vs $32 \%$ of $\beta$-gal ${ }^{+}$cells in Ptf1a ${ }^{\text {Cre/+ }}$; nLacZ (control) rh7 $(p=0.001)$. In Ptf1a ${ }^{\text {Cre/+ }}$; nLacZ (control) rh7, $41 \%$ of $\beta$-gal ${ }^{+}$cells expressed Pax2, and $\sim 16 \%$ of $\beta$-gal ${ }^{+}$cells were located in the ION and did not express either Pax2 or Lmx1b. In Ptf1 $a^{\text {(re//re//nLacZ (Ptf1a }}{ }^{-/}$) mutants, $\beta$-gal ${ }^{+}$cells were not present in the ION, and none of the $\beta$-gal ${ }^{+}$cells expressed Pax2. Scale bars: $A, E, G, F, H, M-T, 200 \mu \mathrm{m} ; B-D, I-L, U-X, 30 \mu \mathrm{m}$. gions, in rh7, Pax2, but not Lmx1b, is expressed in GABAergic neurons.

To label neurons of the Ptfla lineage in E14.5 embryos, we used the Tau- $n L a c Z$ reporter (referred to as $n L a c Z$ throughout this study). The $n L a c Z$ reporter, which contains a LoxP-StopLoxP-nLacZ cassette under the control of a ubiquitous neuronal Tau promoter (Hippenmeyer et al., 2005), was used instead of ROSA26 reporter because it labels neuronal progeny of Creexpressing cells with nuclear $\beta$-gal, helping to more precisely determine the identity of $\beta$-gal ${ }^{+}$cells by colabeling them with nuclear markers. By analyzing $\mathrm{Ptfla}^{\mathrm{Cre} /+}{ }^{+}, \mathrm{LacZ}$ (control) embryos, we found that, in E14.5 rh7, Pax ${ }^{+}$neurons were divided into two groups based on their origin. Dorsolateral Pax $2^{+}$cells were $\beta$-gal ${ }^{+}$and, therefore, originated from Ptfla-expressing progenitors (Fig. $7 E, G, I$, arrowheads). Ventromedial Pax ${ }^{+}$cells were $\beta$-gal ${ }^{-}$(Fig. $7 E, G, J$, arrows) and, therefore, originated from VZ progenitors that did not express Ptf1a. In E14.5 Ptf1 ${ }^{-/-}$ rh7, the dorsolateral group of $\mathrm{Pax}^{+}$cells was absent but the ventrolateral Pax $2^{+}$cells were not affected (Fig. 7 F, H, K, L). Similarly, in $P t f 1 a^{-1-}$ Gad67-GFP embryos, GFP expression was not detected in dorsolateral rh7, while ventromedial GFP signal was still present (Fig. $7 \mathrm{M}, N$ ). Numerous $\beta$-gal ${ }^{+}$cells still populated dorsolateral rh7 in $\mathrm{Ptfla} a^{\mathrm{Cr} / \mathrm{Cre}} ; n \mathrm{LacZ}\left(\mathrm{Ptfla}^{-/-}\right)$embryos (Fig. $7 \mathrm{H}, \mathrm{K}$, open arrowhead), suggesting that, in the absence of $P \operatorname{tfla}$, neurons originating from Ptfla-expressing progenitors do not die, but rather lose Pax2 expression and activity of the Gad67 promoter, suggesting a cell-fate misspecification.

Opposite to the loss of Pax2 expression in dorsolateral cells, the number of $\mathrm{Lmx} 1 \mathrm{~b}^{+}$cells was 2.6-fold higher in $P t f 1 a^{-/-} \mathrm{rh} 7$ compared with controls (Fig. 7O, $P, Y ; p=0.006$ ), and excessive $\mathrm{Lmxlb}^{+}$cells were particularly obvious in dorsomedial (Fig. $7 P, T$, arrow) and ventromedial (Fig. $7 P, T$, arrowhead) areas of rh7. Furthermore, in control E14.5 $\mathrm{Ptfla}^{\mathrm{Cre} /{ }^{+}} ; n \mathrm{LacZ}$ rh7, only $32 \%$ of $\beta$-gal ${ }^{+}$cells expressed Lmx1b (Fig. 7O,Q,S,U,V), while $41 \%$ of $\beta$-gal ${ }^{+}$cells expressed Pax2 (Fig. 7G,I), and $16 \%$ of $\beta$-gal ${ }^{+}$cells were located in the ION and expressed neither Pax2 nor Lmxlb [Fig. 7G,S (quantified in Fig. 7Z)]. In contrast, in Ptfla ${ }^{\mathrm{Cre} / \mathrm{Cre}} ; n \mathrm{LacZ}\left(\mathrm{Ptfla}^{-/-}\right) \mathrm{rh} 7, \sim 85 \%$ of $\beta$-gal ${ }^{+}$cells expressed Lmxlb (Fig. $7 P, R, T, W, X ; p=0.001$ compared with controls), and none of the $\beta$-gal ${ }^{+}$cells expressed Pax2 (Fig. $7 H, K$ ) or populated the ION [Fig. $7 \mathrm{H}, T$ (quantified in Fig. $7 Z$ )]. Together, these data strongly suggest that E14.5 Ptfla ${ }^{-/-}$rh7 contains a large population of misspecified neurons of the Ptfla lineage.

\section{Increased number of $\mathrm{Lmx1b}{ }^{+}$neurons in the $\mathrm{nTs}$ and $\mathrm{SpV}$ nuclei in $P t f 1 a^{-/-}$mice}

To determine the eventual fates of misspecified hindbrain neurons in $\mathrm{Ptfla}^{-1-}$ mice, we analyzed these mutants at E18.5, the last viable stage. In E18.5 embryos, we focused on the nTs and $\mathrm{SpV}$ nuclei, since in earlier Ptfla mutants we observed an increased number of dA3 cells (Fig. $2 F-H$ ), previously described as differentiating $\mathrm{Lmx} 1 \mathrm{~b}^{+} / \mathrm{Phox} 2 \mathrm{~b}^{+}$neurons destined to form the nTs (Qian et al., 2001; Dauger et al., 2003; Sieber et al., 2007; D'Autréaux et al., 2011), and dBLb cells (Fig. $6 E, F, i-K$ ), proposed to contain differentiating $\mathrm{Lmx} 1 \mathrm{~b}^{+}$neurons destined to form the SpV nuclei (Sieber et al., 2007). To identify these nuclei, transverse sections spanning the anterior-posterior axis of E18.5 hindbrain were colabeled with anti-Lmx1b and Phox $2 b$ antibodies. The nTs nuclei were identified as dorsomedial medulla areas densely populated by $\mathrm{Lmx} 1 \mathrm{~b}^{+} / \mathrm{Phox}_{2} \mathrm{~b}^{+}$cells, located directly dorsal to Phox $2 \mathrm{~b}^{+} / \mathrm{Lmx}_{1 \mathrm{~b}}{ }^{-}$vagal motoneurons, while the SpV nuclei were identified on the same sections as lateral medulla areas densely populated by $\mathrm{Lmx} 1 \mathrm{~b}^{+} / \mathrm{Phox}_{2} \mathrm{~b}^{-}$cells (Fig. $8 A$ ), as 

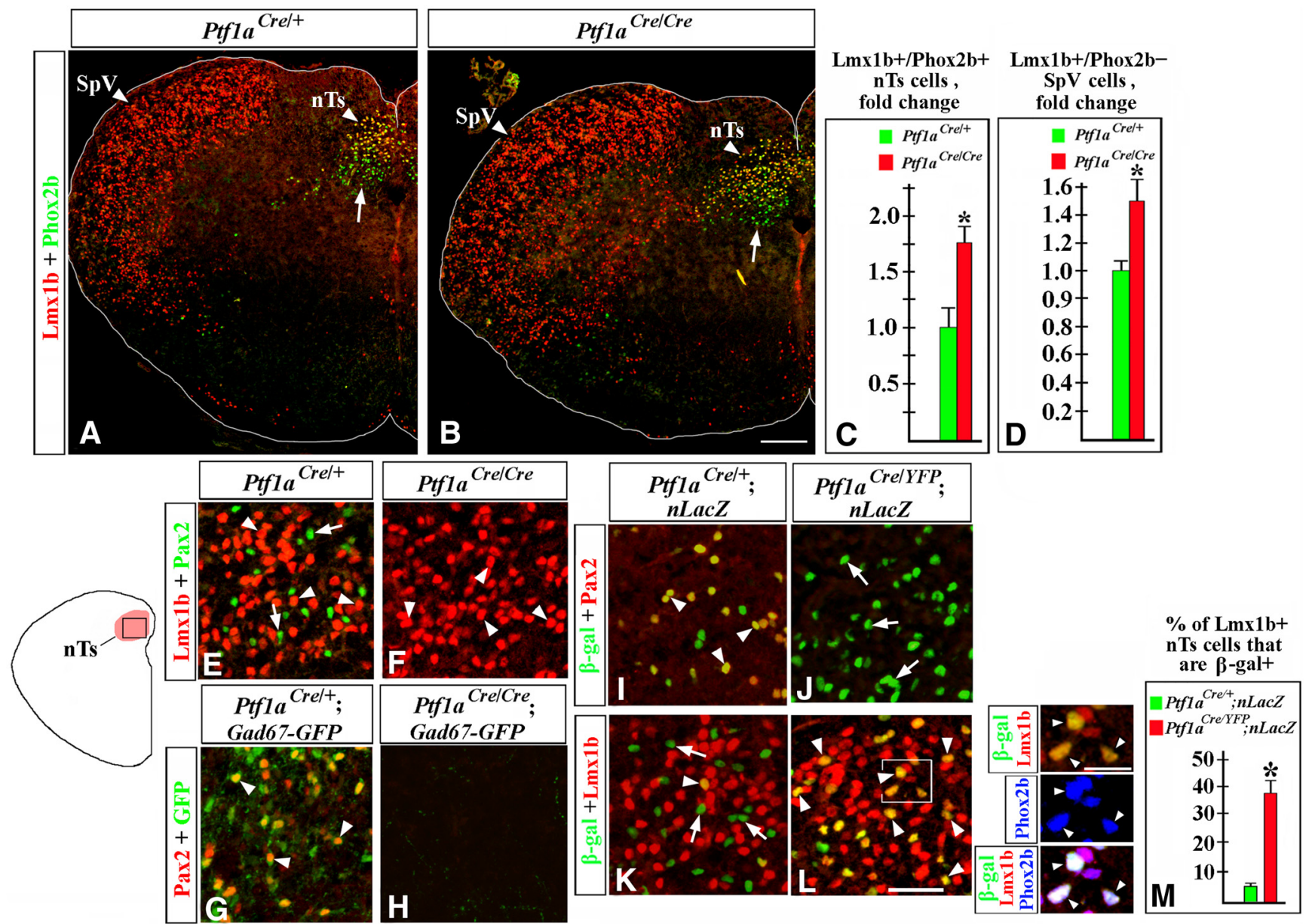

Figure 8. nTs and SpVabnormalities in E18.5Ptf1a ${ }^{-/-}$embryos. Transverse sections of caudal hindbrain with genotypes and antibody markers indicated. $A-D$, An increased number of $L m x 1 b^{+} / P h o x 2 b^{+}$

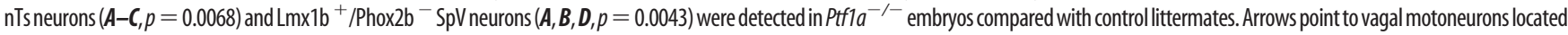
below the $\mathrm{nTs}(\boldsymbol{A}, \boldsymbol{B}) . \boldsymbol{E}-\boldsymbol{L}, \mathrm{An} \mathrm{nTs}$ region boxed in the adjacent diagram. $\boldsymbol{E}, \boldsymbol{F}$, Both $\mathrm{Lmx} 1 \mathrm{~b}^{+}\left(\boldsymbol{E}\right.$, arrowheads) and Pax2 ${ }^{+}\left(\boldsymbol{E}\right.$, arrows) cells were detected in control $\mathrm{nTs}$, but only $\mathrm{Lmx} 1 \mathrm{~b}^{+} \mathrm{nTs}$ neurons $(\boldsymbol{F}$, arrowheads) were present in Ptf1a ${ }^{-1-}$ mutants. G, $\boldsymbol{H}$, In the nTs of Gad67-GFP mice, Pax2 ${ }^{+}$cells coexpressed GFP (G, arrowheads), indicating that they were GABAergic neurons. In Ptf1a ${ }^{-1-}$ Gad67-GFP

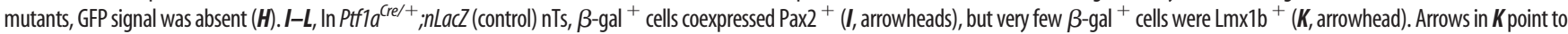

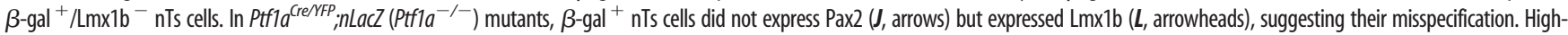
magnification images to the right of $L$ correspond to the region boxed in $L$. In Ptf1a (reerFP, $n L a c Z$ mutants, $L \mathrm{Lmx} 1 \mathrm{~b}^{+} / \beta$-gal ${ }^{+} \mathrm{nTs}$ cells coexpressed Phox $2 \mathrm{~b}$ (arrowheads), showing that they adopted the fate of

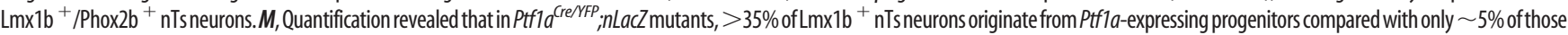
cells in Ptf1a ${ }^{\text {Cre/+ }}$;nLacZ control littermates $(p=0.0064)$. Scale bars: $A, B, 200 \mu \mathrm{m} ; \boldsymbol{E}-\boldsymbol{L}, 40 \mu \mathrm{m} ; \boldsymbol{L}$, inset, $20 \mu \mathrm{m}$.

previously described (Sieber et al., 2007). In E18.5 Ptfla ${ }^{-/-} \mathrm{mu}-$ tants, both $\mathrm{Lmx} 1 \mathrm{~b}^{+} / \mathrm{Phox}_{2} \mathrm{~b}^{+} \mathrm{nTs}$ and $\mathrm{Lmx} 1 \mathrm{~b}^{+} / \mathrm{Phox} 2 \mathrm{~b}^{-} \mathrm{SpV}$ neurons were present at appropriate positions in the brainstem (Fig. $8 A, B$ ). However, there was a significant increase in the number of $\mathrm{Lmxlb}^{+}$neurons in both of these nuclei (an $\sim 1.7$ fold increase in the number of $\mathrm{Lmx}_{\mathrm{B}} \mathrm{b}^{+} \mathrm{nT}$ Ts neurons, $p=0.0068$, and a 1.5-fold increase in the number of $\mathrm{Lmxlb}^{+} \mathrm{SpV}$ neurons, $p=0.0043$, compared with control littermates; Fig. $8 A-D)$. Thus, loss of Ptfla compromises the development of the nTs and SpV nuclei. A detailed analysis of these nuclei in Ptfla mutants is described below.

\section{nTs neurogenesis in the absence of Ptfla}

Immunohistochemical analysis revealed that, in addition to Lmx $1 b^{+} /$Phox $2 b^{+}$cells (Fig. $8 E$, arrowheads), the nTs of E18.5 control embryos contain Pax $2^{+}$cells (Fig. $8 E$, arrows; Sieber et al., 2007). In contrast to $\mathrm{Lmx} 1 \mathrm{~b}^{+} / \mathrm{Phox} \mathrm{b}^{+}$nTs neurons, some of which are noradrenergic (Qian et al., 2001; Sieber et al., 2007), $\mathrm{Pax}^{+}{ }^{+} \mathrm{nT}$ s cells were $\mathrm{GFP}^{+}$in Gad67-GFP mice (Fig. 8G, arrowheads), indicating that they are GABAergic neurons. In E18.5
Ptf1a ${ }^{C r e /+} ; n L a c Z$ (control) embryos, Pax2 ${ }^{+}$nTs neurons were $\beta$-gal ${ }^{+}$(Fig. 8I, arrowheads). In contrast, most $\mathrm{Lmxlb}^{+} \mathrm{nTs}$ neurons were $\beta$-gal ${ }^{-}$in E18.5 Ptfla ${ }^{\mathrm{Cre} /+} ; n L a c Z$ embryos (Fig. $8 K)$, which is consistent with only a small fraction of newborn Lmx $1 b^{+} /$Phox $2 b^{+}$nTs neurons (dA3 cells) labeled by YFP in E11.5 Ptf $1 a^{C r e /+} ;$ ROSA-YFP embryos (Fig. $2 J, k-l l^{\prime \prime}, 3 I-l$ ). Thus, normally $\mathrm{Pax}{ }^{+}$nTs neurons originate from Ptfla-expressing progenitors, while the majority of $\mathrm{Lmxlb}^{+} \mathrm{nTs}$ neurons originate from progenitors that do express Ptfla.

In E18.5 Ptfla $\mathrm{a}^{-/-}$mice, Pax2 ${ }^{+}$neurons were not detected in the nTs, and there was no GFP expression in the nTs of Ptf1a $a^{-1-}$ Gad67-GFP mice (Fig. 8E-H). To investigate whether $P t f 1 a^{-/-}$nTs contain misspecified neurons, we ana-

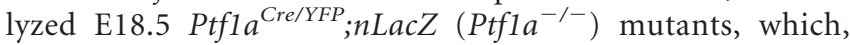
similar to Ptfla $\mathrm{C}^{\mathrm{Cr} /+}$ controls, contained one Cre copy in their genome. In these mutants, numerous $\beta$-gal ${ }^{+}$cells were detected in the nTs, arguing that, even in the absence of Ptfla, cells of the Ptfla lineage contribute to the nTs. However, in contrast to $\beta$-gal ${ }^{+}$cells in the nTs of $P t f 1 a^{C r e /+} ; n L a c Z$ control mice, in Ptf1a $a^{\text {Cre/YFP }} ; n L a c Z\left(P t f 1 a^{-/-}\right)$embryos virtually all 
$\beta$-gal ${ }^{+} \mathrm{nTs}$ cells expressed Lmx1b rather than Pax2 (Fig. 8I$L)$. Cell counts revealed that in Ptfla ${ }^{\text {Cre/YFP }} ; n L a c Z\left(P_{f t} 1 a^{-/-}\right)$ mutants, $>35 \%$ of $\mathrm{Lmxlb}^{+}$nTs neurons were $\beta$-gal ${ }^{+}$, compared with only $\sim 5 \%$ of $\mathrm{Lmxlb}^{+}$neurons that expressed $\beta$-gal in the nTs of Ptfla $a^{\mathrm{Cre} /+} ; n L a c Z$ control littermates $(p=$ 0.0064; Fig. $8 M$ ). Similar to $\mathrm{Lmx} 1 \mathrm{~b}^{+} \mathrm{nTs}$ neurons originating from $\mathrm{Ptfla}^{-}$progenitors, in Ptf1a ${ }^{\mathrm{Cre} / Y F P} ; n L a c Z\left(\mathrm{Ptfla}^{-/-}\right)$ mutants, Lmx1b ${ }^{+} / \beta$-gal ${ }^{+}$nTs neurons coexpressed Phox $2 \mathrm{~b}$ (Fig. $8 L$, insets). Thus, in the absence of Ptf1a, Pax ${ }^{+}$GABAergic nTs neurons are absent, and the nTs nuclei become populated by supernumerary $\operatorname{Lmx} 1 \mathrm{~b}^{+} / \mathrm{Phox} 2 \mathrm{~b}^{+}$neurons, some of which aberrantly arise from Ptfla-expressing progenitors.

We next performed birth-dating experiments to directly identify when misspecified nTs neurons are produced in $\mathrm{Ptfla}^{-/-}$mutants. Ptfla ${ }^{\mathrm{Cre} /+} ; n \mathrm{LacZ}$ (control) and Ptfla ${ }^{\mathrm{Cre} / \mathrm{YFP}}$; $n L a c Z\left(P t f 1 a^{-/-}\right)$mice were injected with BrdU at E11, during an early phase of hindbrain neurogenesis, or at E12.25, during a late phase of neurogenesis, and were analyzed at E18.5, when the nTs is formed. BrdU is incorporated into DNA during the $S$ phase of the cell cycle, and cells that exit their last cell cycle and differentiate shortly after the BrdU injection become heavily labeled by BrdU (Rash et al., 2013).

In control embryos, a fraction of $\mathrm{Pax} 2^{+} \mathrm{nT}$ s neurons were $\mathrm{BrdU}^{+}$when BrdU was injected at both E11 (Fig. 9A, $a$, arrowheads) and E12.25 (Fig. 9D, $d$, arrowheads), suggesting that these neurons arise during an extended time period. Colabeling with $\beta$-gal in Ptfla $a^{\mathrm{Cre} /+} ; n \mathrm{LacZ}$ (control) embryos confirmed that during both early and late neurogenesis $\mathrm{Pax} 2^{+}$ $\mathrm{nTs}$ neurons arise from Ptf1 $a$-expressing progenitors (Fig. $9 a-$ $\left.a^{\prime \prime}, d-d^{\prime \prime}\right)$. In E18.5 control embryos, a fraction of Lmx1b ${ }^{+} \mathrm{nTs}$ neurons were $\mathrm{BrdU}^{+}$when BrdU was injected at E11 (Fig. $9 B, b$, arrowheads), but virtually no $\mathrm{Lmxlb}^{+} / \mathrm{BrdU}^{+}$cells were detected when BrdU was injected at E12.25 (Fig. 9E), confirming previous observations that $\mathrm{Lmx} 1 \mathrm{~b}^{+} \mathrm{nT}$ s neurons are predominantly generated during an early phase of hindbrain neurogenesis (Qian et al., 2001; Sieber et al., 2007).

In E18.5 Ptf1a ${ }^{-/-}$mutants, similar to control embryos, a fraction of $\mathrm{Lmxlb}{ }^{+} \mathrm{nT}$ s neurons were $\mathrm{BrdU}^{+}$when BrdU was injected at E11 but not at E12.25 (Fig. 9C, $c$, arrowheads, $F$ ). In Ptfla $a^{C r e / Y F P}$; nLacZ embryos injected at E11, some $\mathrm{BrdU}^{+} /$ Lmx1b ${ }^{+}$cells were also $\beta$-gal ${ }^{+}$(Fig. $9 c-c^{\prime \prime}$, arrowheads), revealing that in Ptfla $a^{-/-}$mutants, at least some misspecified $\mathrm{Lmxlb}^{+} \mathrm{nT}$ s neurons arise from Ptfla-expressing progenitors during early neurogenesis. Since in wild-type embryos Lmx $1 b^{+} /$Phox $2 b^{+}$nTs neurons are generated during early but not late neurogenesis, it is likely that excessive $\mathrm{Lmx} 1 \mathrm{~b}^{+}$ neurons arising in $P t f 1 a^{-/-}$rh7 during late neurogenesis (Fig. $6 E-K)$ are not competent to populate the nTs. Notably, although we did not find a difference in the number of Casp $3^{+}$ apoptotic cells in the nTs of control and $\mathrm{Ptfla}^{-/-}$mice at E18.5 (Fig. 10A-C), the number of apoptotic cells was increased in the Ptfla $a^{-/-}$nTs at E14.5 ( $p=0.03$; Fig. 10D-J), with some Casp $3^{+}$cells coexpressing Lmx1b and Phox $2 b$ (Fig. $10 G-i)$. Thus, it is possible that in Ptfla mutants some lateborn Ptf1a lineage neurons also aberrantly adopt the fate of $\mathrm{Lmxlb}^{+} \mathrm{nT}$ s neurons but do not survive until E18.5.

\section{$\mathrm{SpV}$ neurogenesis in the absence of Ptfla}

Immunohistochemical analysis revealed that in addition to $\mathrm{Lmx} \mathrm{b}^{+}$neurons (Fig. $11 A, B, D$, arrowheads), E18.5 wild-type $\mathrm{SpV}$ nuclei contain numerous Pax ${ }^{+}$cells (Fig. $11 B, D$, arrows). Based on the coexpression of Tlx3, a marker and determinant of excitatory cell fate in the CNS (Qian et al., 2001; Cheng et al.,
2004; Glasgow et al., 2005; Xiang et al., 2012), Lmx1b ${ }^{+} \mathrm{SpV}$ neurons were previously proposed to be excitatory neurons (Dai et al., 2008). In the SpV nuclei of E18.5 Gad67-GFP embryos, $\mathrm{Pax}^{+}$(Fig. $11 \mathrm{H}$, arrowheads), but not $\mathrm{Lmxlb}^{+}$(data not shown), cells were $\mathrm{GFP}^{+}$, indicating that $\mathrm{Pax} 2^{+}$cells in the $\mathrm{SpV}$ nuclei are GABAergic neurons. In the $\mathrm{SpV}$ nuclei of E18.5 Ptfla ${ }^{\mathrm{Cre} /+}$; $n \mathrm{LacZ}$ (control) embryos, both Pax ${ }^{+}$and Lmx1b ${ }^{+}$ neurons were labeled by $\beta$-gal (Fig. $11 \mathrm{~J}, L$ ), arguing that both these populations originate from Ptfla-expressing progenitors. $\beta$-gal labeling of Lmx1b ${ }^{+} \mathrm{SpV}$ neurons in E18.5 Ptfla ${ }^{\mathrm{Cre} /+} ; n \mathrm{LacZ}$ embryos is consistent with $\beta$-gal labeling of dBLb cells in E12.5 Ptfla ${ }^{\mathrm{Cre} /+}$;ROSA-LacZ embryos (Fig. $6 \mathrm{R}$ ), the cellular population proposed to contain differentiating $\mathrm{Lmx} 1 \mathrm{~b}^{+}$neurons of the $\mathrm{SpV}$ (Sieber et al., 2007).

In E18.5 $\mathrm{Ptfla}^{-/-}$embryos, no Pax ${ }^{+}$cells were detected in the SpV nuclei (Fig. 11C,E), and there was no GFP signal in the SpV nuclei of Ptfla $a^{-/-}$Gad67-GFP mice (Fig. 11I). At the same time point, similar to wild-type mice, $\mathrm{Lmxlb}{ }^{+} \mathrm{SpV}$ neurons in $P t f 1 a^{-/-}$mice expressed their appropriate cell type-specific marker Tlx3 (Fig. $11 F, G)$. In Ptfla ${ }^{C r e / Y F P}$;nLacZ $\left(P t f 1 a^{-/-}\right.$) embryos, $\mathrm{Lmxlb}^{+} \mathrm{SpV}$ neurons were $\beta$-gal ${ }^{+}$, indicating that, as in wild-type mice, they were generated from Ptfla-expressing progenitors (Fig. $11 \mathrm{~L}, \mathrm{M}$ ). In contrast to control E18.5 $\mathrm{Ptfla}^{\mathrm{Cre} /+}$; nLacZ embryos, where approximately one-half of $\beta$-gal ${ }^{+}$cells in the SpV expressed Lmx1b, while the other half expressed Pax2, in Ptfla ${ }^{\text {Cre/YFP }}$;nLacZ mutants the vast majority of $\beta$-gal ${ }^{+} \mathrm{SpV}$ cells were $\mathrm{Lmxlb}^{+}$(Fig. 11J-M). There were an increased number of $\mathrm{Casp}^{+}$apoptotic cells in the SpV nuclei of $\mathrm{Ptfl} \mathrm{a}^{-/-}$mutants $(p=0.003$ compared with controls; Fig. $11 N-T)$. In Ptfla ${ }^{-/-}$ mutants, some of these Casp $3^{+}$cells were $\mathrm{Lmx1b}{ }^{+}$(Fig. $11 P-s$ ), showing that, in the absence of Ptfla, Lmxlb ${ }^{+} \mathrm{SpV}$ neurons excessively die. Together, our data indicate that loss of Ptfla prevents populating the $\mathrm{SpV}$ nuclei with $\mathrm{Pax} 2{ }^{+}$GABAergic neurons. In contrast, although $\mathrm{Lmxlb}^{+} \mathrm{SpV}$ neurons originate from Ptfla-expressing progenitors, the loss of Ptf1a does not prevent the generation of these neurons. Furthermore, since $\mathrm{Lmxlb}^{+}$neurons were increased in the number in $\mathrm{Ptfla} \mathrm{a}^{-1-}$ SpV nuclei (Fig. 8A,B,D), Ptfla prevents their excessive production. At the same time, since we observed an increased number of apoptotic Lmx1b ${ }^{+}$neurons in the Ptf1a ${ }^{-/-} \mathrm{SpV}$ nuclei, Ptfla may be necessary for the survival of $\mathrm{Lmx} 1 \mathrm{~b}^{+} \mathrm{SpV}$ neurons, although excessive apoptosis of these cells in Ptfla $a^{-/-}$mutants may be a secondary response to a lack of $\mathrm{Pax} 2{ }^{+}$GABAergic SpV neurons.

To directly analyze when $\mathrm{SpV}$ neurons are generated in $P t f 1 a^{-1-}$ mutants, we performed BrdU birth-dating experiments. Ptfla ${ }^{\mathrm{Cre} /+} ; n \mathrm{LacZ}$ (control) and Ptfla ${ }^{\mathrm{Cre} / Y F P} ; n L a c Z$ $\left(P t f 1 a^{-/-}\right)$mice were injected with BrdU at E11, during an early phase of hindbrain neurogenesis, or at E12.25, during a late phase of neurogenesis, and were analyzed at E18.5, when the SpV nuclei are already formed. In wild-type embryos, a fraction of Pax $2^{+}$ $\mathrm{SpV}$ neurons were $\mathrm{BrdU}^{+}$when BrdU was injected at both E11 (Fig. 12A, b, arrowheads) and E12.25 (Fig. 12O,p, arrowheads), suggesting that these neurons arise during an extended time period. $\beta$-gal colabeling in $\mathrm{Ptfla}^{\mathrm{Cre} /+} ; n \mathrm{LacZ}$ (control) embryos confirmed that during both early and late neurogenesis, $\mathrm{Pax} 2^{+} \mathrm{SpV}$ neurons arise from Ptfla-expressing progenitors (Fig. $12 b-d, p-$ $r)$. Many Lmxlb ${ }^{+}$neurons were BrdU ${ }^{+}$when control mice were injected with BrdU at E12.25 (Fig. 12S,t). These $\mathrm{Lmx} 1 \mathrm{~b}^{+} / \mathrm{BrdU}^{+}$ cells were $\beta$-gal ${ }^{+}$in $\mathrm{Ptfla} \mathrm{Cre}^{\mathrm{C}}$; nLacZ (control) embryos (Fig. $12 t-v)$, confirming that they originate from Ptfla-expressing progenitors. Few $\mathrm{Lmxlb}^{+} / \mathrm{BrdU}^{+} \mathrm{SpV}$ cells were observed when $\mathrm{Ptfla}^{\mathrm{Cre} /+}$;nLacZ mice were injected with BrdU at E11 (Fig. 12E). 
BrdU e11 $\rightarrow \mathrm{e} 18.5$
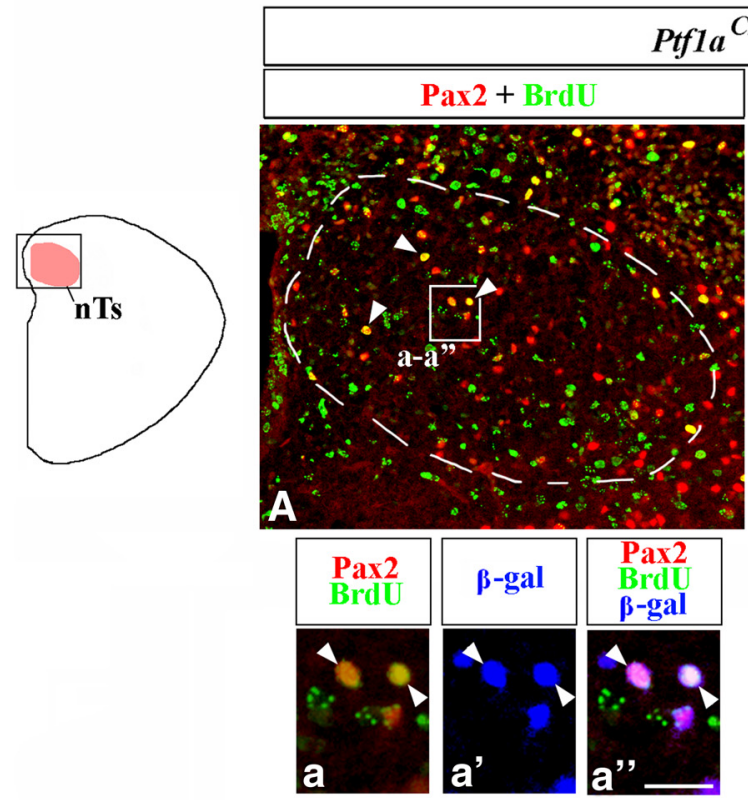

B
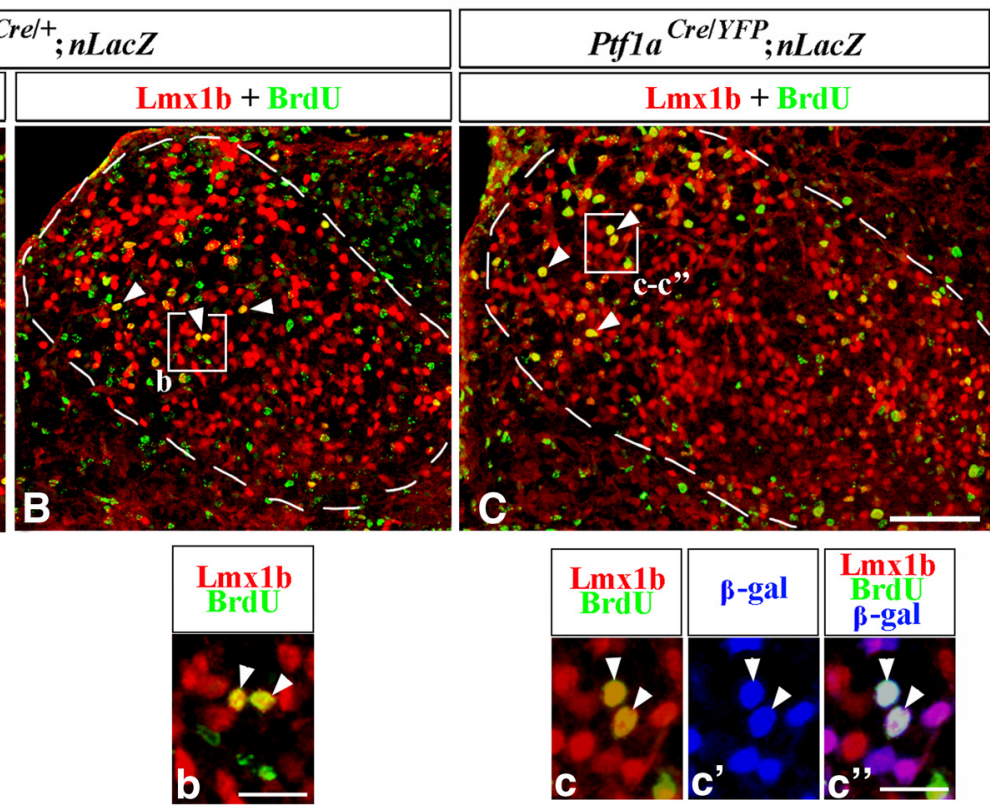

BrdU e12.25 $\rightarrow$ e18.5
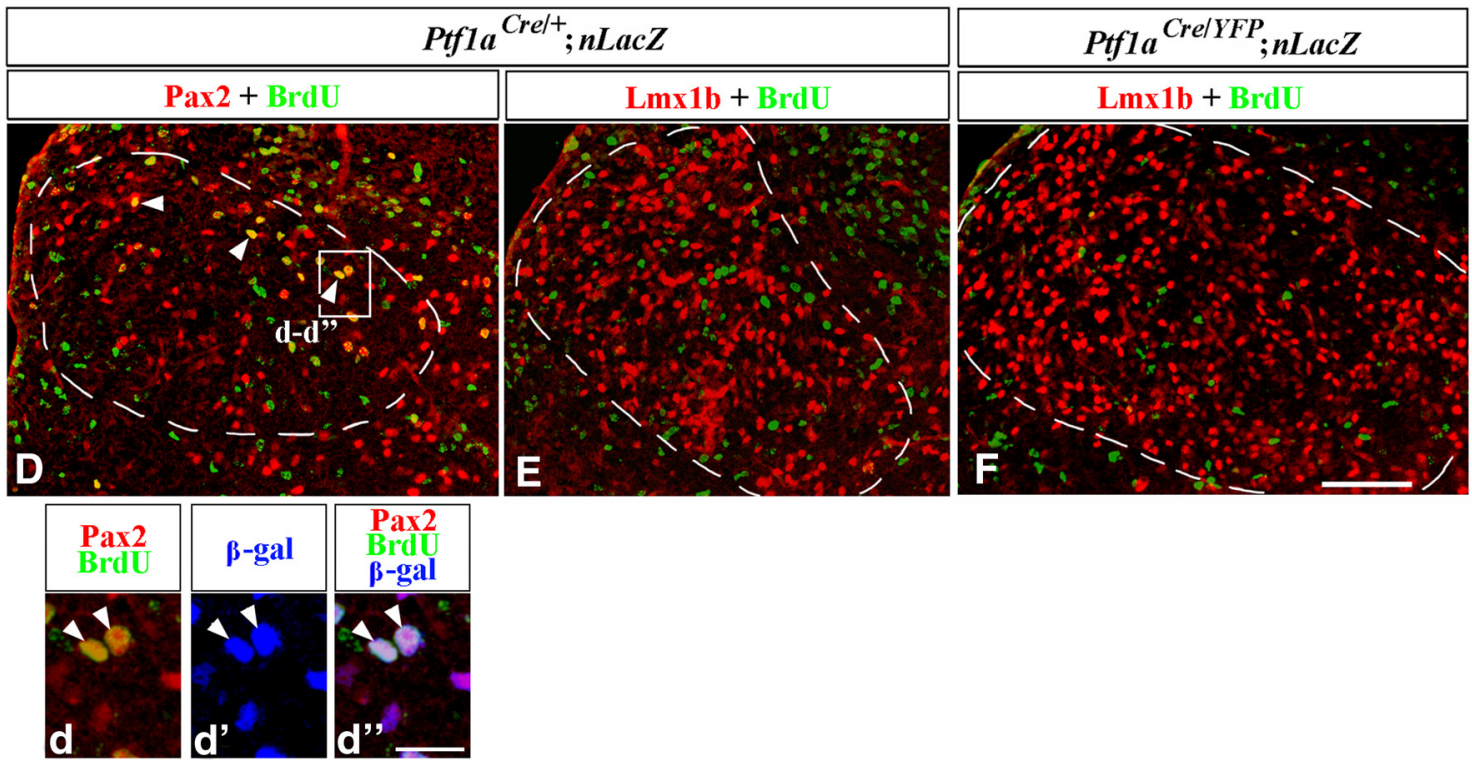

Figure 9. Birth-dating analysis of nTs neurons in $P t f 1 a^{-/-}$mice. Transverse sections through the nTs with genotypes and antibody markers indicated. $\boldsymbol{A}-\boldsymbol{F}$, Mice were injected with BrdU at E11 $(\boldsymbol{A}-\boldsymbol{C})$ or E12.25 (D-F) and were analyzed at E18.5. $\boldsymbol{A}-\boldsymbol{F}$ show a dorsal area, including the nTs, boxed in the schematic. The nTs is outlined by a dashed line. Magnified regions in $\boldsymbol{a}-\boldsymbol{a}^{\prime \prime}, \boldsymbol{b}, \boldsymbol{C}-\boldsymbol{C}^{\prime \prime}, \boldsymbol{d}-\boldsymbol{d}^{\prime \prime}$ correspond to areas boxed in adjacent data panels. In Ptf1 ${ }^{\text {Cre/+}}{ }^{+}$nL LacZ (control) embryos some Pax2 ${ }^{+}$cells were labeled by BrdU, when BrdU was injected at both E11 and E12.25 (A, $\boldsymbol{D}$, arrowheads).

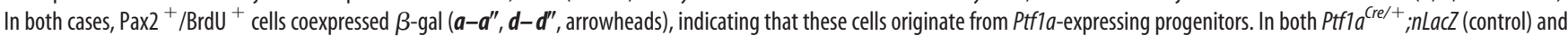

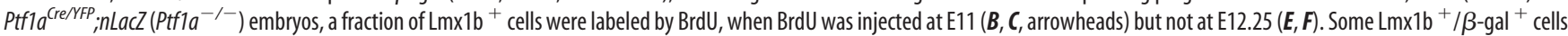

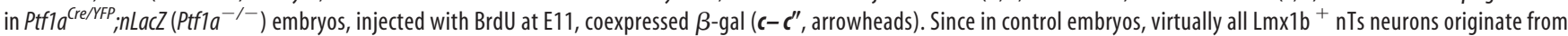

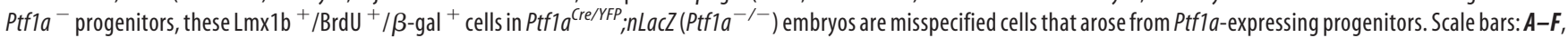
$100 \mu \mathrm{m} ; \boldsymbol{a}-\boldsymbol{a}^{\prime \prime}, \boldsymbol{b}, \boldsymbol{c}-\boldsymbol{c}^{\prime \prime}, \boldsymbol{d}-\boldsymbol{d}^{\prime \prime}, 25 \mu \mathrm{m}$.

Furthermore, rather than being heavily labeled with BrdU, a majority of these $\mathrm{Lmxlb}^{+} / \mathrm{BrdU}^{+} / \beta$-gal ${ }^{+}$cells contained only one to three small BrdU ${ }^{+}$dots (Fig. 12E-i), suggesting that after BrdU incorporation at E11, these cells underwent one or two additional divisions before finally exiting the cell cycle (Rash et al., 2013). Thus, our data indicate that in wildtype embryos most $\mathrm{Lmxlb}^{+} \mathrm{SpV}$ neurons arise during late neurogenesis, consistent with previous studies, which proposed late-born dBLb cells as newly generated SpV Lmx1b ${ }^{+}$ neurons (Sieber et al., 2007).
In E18.5 Ptfla $\mathrm{C}^{\mathrm{Cr} / \mathrm{YFP}} / \mathrm{nLacZ}\left(\mathrm{Ptfla}^{-/-}\right)$mutants, similar to control embryos, a fraction of $\mathrm{Lmxlb}^{+} \mathrm{SpV}$ neurons were $\mathrm{BrdU}^{+}$when BrdU was injected at E12.25 (Fig. $12 \mathrm{~W}$, $x$, arrowheads). Cell counts revealed an increased number of $\mathrm{Lmx} \mathrm{b}^{+} /$ $\mathrm{BrdU}^{+} \mathrm{SpV}$ cells in these mutants relative to control littermates $(p=0.0083$; Fig. 12A1), arguing that an increased number of $\mathrm{Lmxlb}^{+} \mathrm{SpV}$ neurons in E18.5 Ptf1a mutants are at least partially emerging from their excessive production during late neurogenesis. In addition, and in contrast to wild-type embryos, many $\mathrm{Lmx} 1 \mathrm{~b}^{+} \mathrm{SpV}$ cells were heavily labeled with BrdU when BrdU 


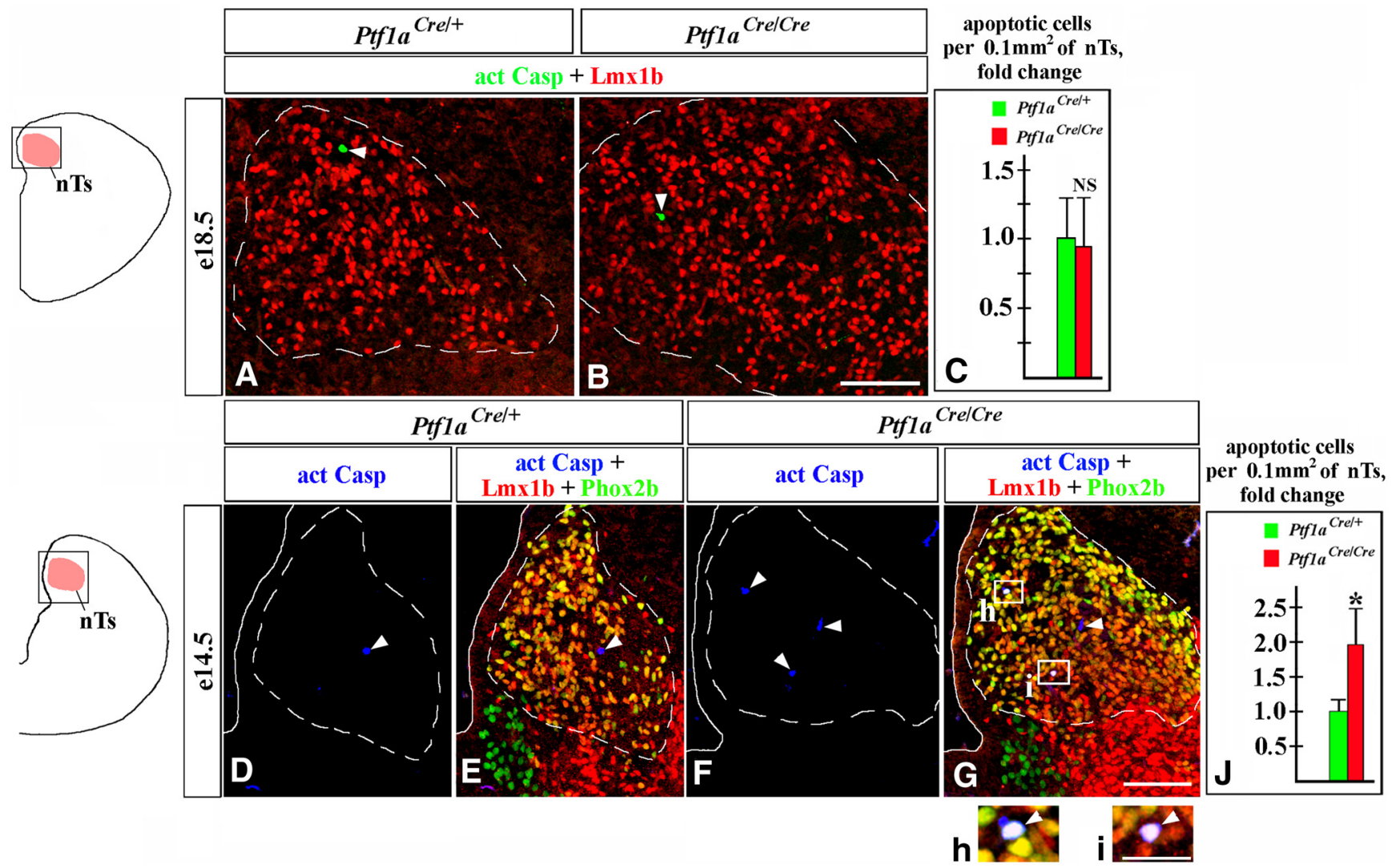

Figure 10. Increased apoptosis in the nTs of E14.5 but not E18.5 Ptf1a ${ }^{-/-}$embryos. Transverse sections through the nTs with genotypes and antibody markers indicated. Images in data panels correspond to area boxed in adjacent schematics. $\boldsymbol{A}-\boldsymbol{J}$, More Casp $3^{+}$apoptotic cells (arrowheads) were present in the nTs of Ptf1 $a^{-1-}$ mutants relative to controls at E14.5 (D-J,p $\left.=0.03\right)$ but not at E18.5 ( $\boldsymbol{A}-\boldsymbol{C} ;$ NS, nonsignificant). In E14.5 Ptf1a ${ }^{-/-}$mutants, some apoptotic cells coexpressed Lmx1b and Phox2b ( $\boldsymbol{h}$, $\boldsymbol{i}$, white cells pointed out by arrowheads), indicating that they were $n T s$ neurons belonging to the $L m \times 1 b$ lineage. Scale bars: $\boldsymbol{A}, \boldsymbol{B}, \boldsymbol{D}-\mathbf{G}, 100 \mu \mathrm{m} ; \boldsymbol{h}, \boldsymbol{i}, 30 \mu \mathrm{m}$.

was injected at E11 (Fig. 12E,J,k,l,n). Similar to Lmx1b ${ }^{+} \mathrm{SpV}$ neurons labeled by BrdU injection at E12.25, many Lmx1b ${ }^{+} \mathrm{SpV}$ neurons labeled by BrdU injection at E11 were clearly $\beta$-gal ${ }^{+}$in $P t f 1 a^{C r e / Y F P} ; \mathrm{nLacZ}\left(P t f 1 a^{-/-}\right)$embryos, indicating that they originate from $P t f 1 a$-expressing progenitors (Fig. $12 k-n, x-z$ ). Thus, based on our birth-dating studies, in the absence of Ptfla, more $\mathrm{Lmxlb}^{+} \mathrm{SpV}$ neurons are produced during late neurogenesis. Furthermore, in contrast to wild-type embryos, in $\mathrm{Ptfla}^{-/-} \mathrm{mu}-$ tants, a significant fraction of $\mathrm{Lmxlb}^{+} \mathrm{SpV}$ neurons arise not only during a late phase of neurogenesis, but also during an early phase.

\section{Loss of Ptfla compromises neuronal composition of the PrV nuclei}

In addition to the SpV nuclei, the PrV nuclei is another critical center of somatosensory information integration (Woolsey, 1990). Mouse genetic fate mapping revealed that, in contrast to the SpV nuclei that develop in caudal brainstem, PrV neurons arise in rh2-3 (Oury et al., 2006). The PrV nuclei contain both $\mathrm{Lmx}_{\mathrm{b}} \mathrm{b}^{+}$cells (Fig. $13 \mathrm{~A}, B, D$, arrowheads), which are glutamatergic excitatory neurons (Xiang et al., 2012), and Pax $2^{+}$cells (Fig. $13 B, D$, arrows), which are GABAergic inhibitory neurons (Fig. 13F; Xiang et al., 2012). In E18.5 $\mathrm{Ptfla}^{\mathrm{Cre} /+}$; nLacZ embryos, virtually all $\mathrm{Pax} 2{ }^{+} \mathrm{PrV}$ neurons were $\beta$-gal ${ }^{+}$, but the vast majority of $\mathrm{Lmx} 1 \mathrm{~b}^{+} \mathrm{PrV}$ neurons were $\beta$-gal ${ }^{-}$, indicating that $\mathrm{Pax} 2^{+}$, but not $\mathrm{Lmxlb}^{+}$, PrV neurons normally originate from Ptflaexpressing progenitors (Fig. $13 \mathrm{H}, \mathrm{J}$ ). In E18.5 $\mathrm{Ptfla^{-/- }}$ embryos, $\mathrm{Pax} 2{ }^{+}$neurons appeared reduced in number but were not completely lost (Fig. 13B-E). Furthermore, similar to control mice, some Pax $2^{+}$PrV neurons in Ptf1a $a^{-/-}$Gad67-GFP mutants were $\mathrm{GFP}^{+}$, arguing that they maintain the identity of GABAergic inhibitory neurons (Fig. $13 F, G$ ). Interestingly, and in contrast to Ptfla ${ }^{\mathrm{Cre} /+}$; $n \mathrm{LacZ}$ control embryos, in E18.5 Ptfla ${ }^{\mathrm{Cre} / Y F P} ; n L a c Z$ $\left(P t f 1 a^{-/-}\right)$mutants, none of the $\beta$-gal ${ }^{+}$cells populating the $\operatorname{PrV}$ nuclei expressed Pax2 (Fig. $13 \mathrm{H}, I$ ). Instead, virtually all of these $\beta$-gal ${ }^{+}$cells expressed Lmx1b (Fig. $13 \mathrm{~K}$ ). As a result, in the PrV nuclei of E18.5 Ptf1a ${ }^{\text {Cre/YFP }}$; $n$ LacZ mutants, $\sim 25 \%$ of Lmx1b ${ }^{+}$ neurons were $\beta$-gal ${ }^{+}$(compared with $<3 \%$ of Lmxlb ${ }^{+}$PrV neurons in control littermates, $p=0.0006$; Fig. $13 J-L)$. Thus, rather than producing Pax $2^{+} \operatorname{PrV}$ neurons, in the absence of Ptfla, Ptfla-expressing progenitors produce $\mathrm{Lmx} 1 \mathrm{~b}^{+} \operatorname{PrV}$ neurons. Considering that $\mathrm{Pax} 2^{+} \mathrm{PrV}$ cells were $\beta$-gal ${ }^{+}$in $\mathrm{Ptfla}{ }^{\mathrm{Cre} /+}$; $n L a c Z$ embryos, but were $\beta$-gal ${ }^{-}$in $P t f 1 a^{\text {Cre/YFP }} ; n L a c Z$ embryos, it is possible that in Ptfla mutants the loss of Pax $2^{+} \operatorname{PrV}$ cells belonging to the Ptf1a lineage is partially compensated by Pax $2^{+}$ neurons originating from a $P t f 1 a^{-}$lineage.

\section{Discussion}

In the brainstem, Ptfla was implicated in the differentiation and survival of ION and cochlear neurons (Yamada et al., 2007, Fujiyama et al., 2009). Here, we show that the loss of Ptf1a prevents the development of GABAergic neurons populating viscerosensory and somatosensory brainstem nuclei. We find that the formation of 3 (dA4, dB1, and dBLa) of the $10 \mathrm{dA} / \mathrm{dB}$ and $\mathrm{dBLa} / \mathrm{b}$ populations in the dorsal hindbrain depends on Ptf1a. Our data argue that in the brainstem Ptfla acts largely as a regulator of cell-fate specification decisions, suppressing an $\mathrm{Lmxlb}^{+}$fate in subsets of differentiating cells. 

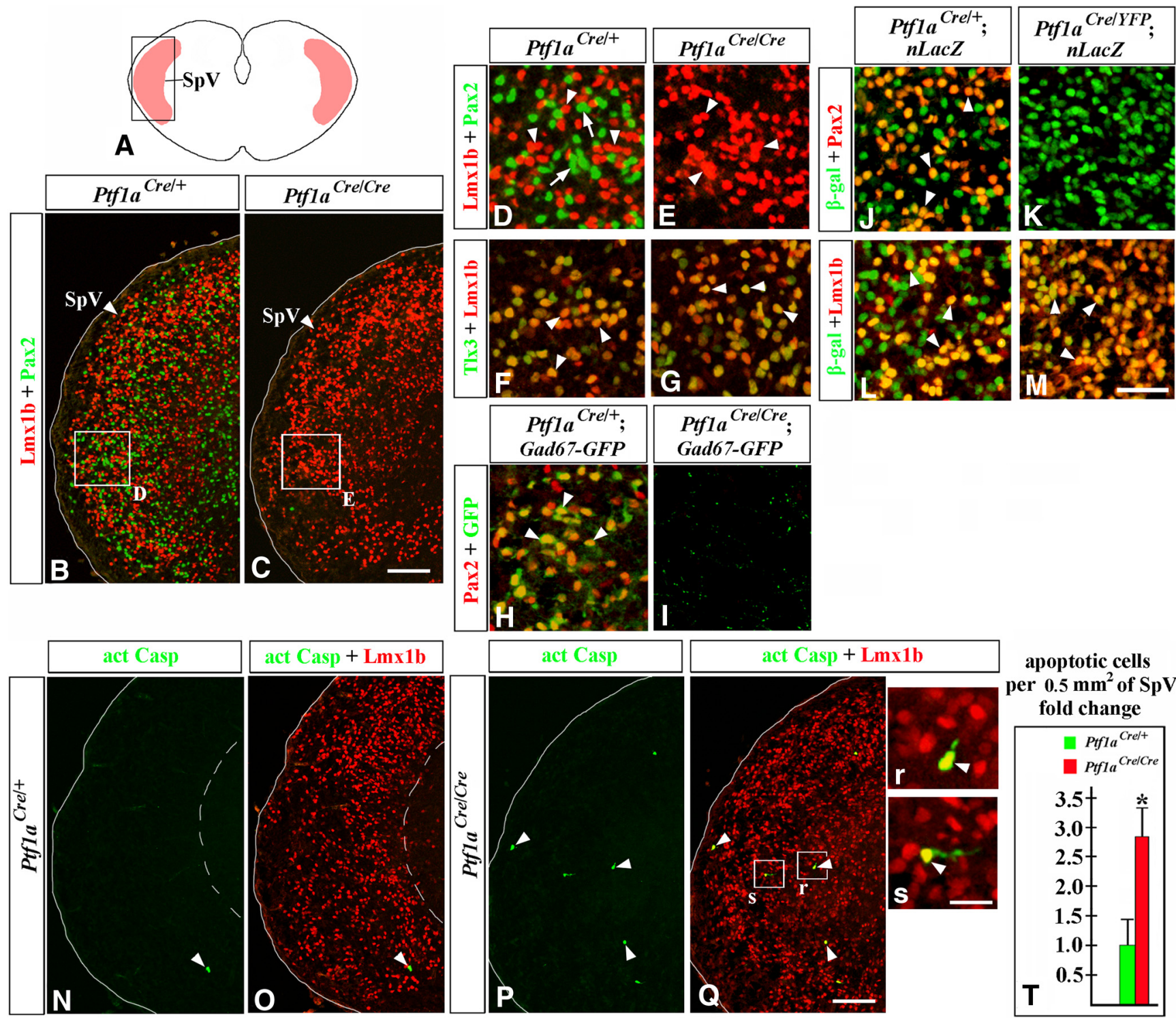

apoptotic cells per $0.5 \mathrm{~mm}^{2}$ of $\mathrm{SpV}$ fold change

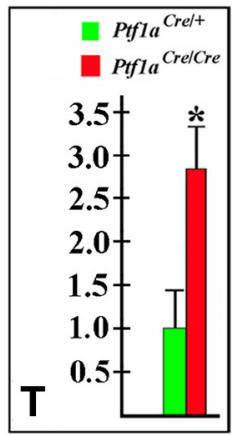

Figure 11. Lack of $\mathrm{Pax2} 2^{+} \mathrm{GABAergic} \mathrm{neurons} \mathrm{in} \mathrm{the} \mathrm{SpV} \mathrm{nuclei} \mathrm{of} \mathrm{E} 18.5 \mathrm{Ptf1a^{-/ }}$ embryos. Transverse sections of caudal hindbrain with genotypes and antibody markers indicated. Images in $\boldsymbol{B}, \boldsymbol{C}$, and $\boldsymbol{N}-\mathbf{Q}$ correspond to the area boxed in the schematic $\boldsymbol{A}$. High-magnification images correspond to regions boxed in adjacent data panels. $\boldsymbol{B}-\boldsymbol{E}, \mathrm{Both}_{\mathrm{L}} \mathrm{Lmx}_{1 \mathrm{~b}}{ }^{+}(\boldsymbol{B}, \boldsymbol{D}$, arrowheads $)$ and Pax ${ }^{+}$ $\left(\boldsymbol{B}, \boldsymbol{D}\right.$, arrows) SpV neurons were detected in controls, but only $\mathbf{L m x} 1 \mathrm{~b}^{+} \mathrm{SpV}$ neurons $\left(\boldsymbol{C}, \boldsymbol{E}\right.$, arrowheads) were present in $P t f 1 a^{-/-}$mutants. $\boldsymbol{F}, \boldsymbol{G}, \mathrm{Lmx} 1 \mathrm{~b}^{+}$SpV neurons coexpressed Tlx3 in both controls and Ptf1a ${ }^{-/-}$mutants (arrowheads). $\boldsymbol{H}, \boldsymbol{I}$, In the SpV nuclei of Gad67-GFP mice, Pax2 ${ }^{+}$cells coexpressed GFP ( $\boldsymbol{H}$, arrowheads), suggesting that they were GABAergic neurons. $\boldsymbol{I}$, In Ptf1a $^{-1-}$ Gad67-GFP mutants, GFP signal was absent. J-M, In the Ptf1a ${ }^{\text {Cre/+ }}$; LacZ (control) SpV nuclei, some $\beta$-gal ${ }^{+}$cells coexpress Pax2 (J, arrowheads), while others coexpress $L$ mx1b ( $L$,

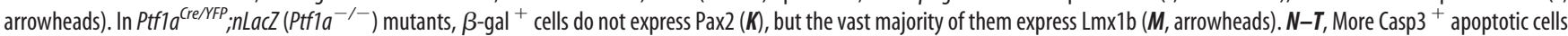
(arrowheads) were present in the SpV region of $P t f 1 a^{-/-}$mutants relative to controls $(\boldsymbol{T}, p=0.003)$. In Ptf1a ${ }^{-/-}$mutants, some apoptoticcells coexpress $L \mathrm{Lx} 1 \mathrm{~b}(\boldsymbol{P}, \boldsymbol{Q}, \boldsymbol{r}, \boldsymbol{s}$, arrowheads).Scale bars: $B, C, N-Q, 100 \mu \mathrm{m} ; \mathbf{D}-\mathbf{M}, 40 \mu \mathrm{m} ; \boldsymbol{r}, \mathbf{s}, 20 \mu \mathrm{m}$.

Ptfla is necessary for development of viscerosensory and somatosensory GABAergic brainstem neurons

Both viscerosensory (nTs) and somatosensory ( $\mathrm{SpV}$ and $\mathrm{PrV}$ ) nuclei contain neurons of the $L m x 1 b$ lineage. $L m x 1 b^{+}$viscerosensory and somatosensory neurons share a similar gene expression profile, suggesting common developmental and evolutionary origin of viscerosensory and somatosensory brainstem nuclei (Qian et al., 2002; D’Autréaux et al., 2011; Nomaksteinsky et al., 2013). We show that, in addition to neurons of the $L m \times 1 b$ lineage, another common feature of the $\mathrm{nTs}, \mathrm{SpV}$, and PrV nuclei, is that each contain Pax ${ }^{+}$GABAergic neurons that originate from $P t f 1 a$-expressing progenitors and require Ptfla for development. While several genes, including $L b x 1$, Phox $2 b, A s c l 1$, and $T l x 1 / 3$, are known to regulate the development of Lmx $1 b^{+}$brainstem neurons (Qian et al., 2001, 2002; Sieber et al., 2007; D'Autréaux et al., 2011), to our knowledge, Ptfla is the first gene required for specification of $\mathrm{Pax} 2{ }^{+}$GABAergic viscerosensory and somatosensory brainstem neurons.

In the developing brainstem, Ptfla primarily acts as a regulator of cell-fate specification

Our data support the conclusion that in $\mathrm{Ptfla}^{-/-}$mutants, the loss of GABAergic nTs and SpV neurons is caused by a cell-fate misspecification during both early (E11-E11.5) and late (E12.5) neurogenesis, which affects not only viscerosensory and somatosensory neurons, but at least one additional population, the climbing fiber neurons of the ION. 

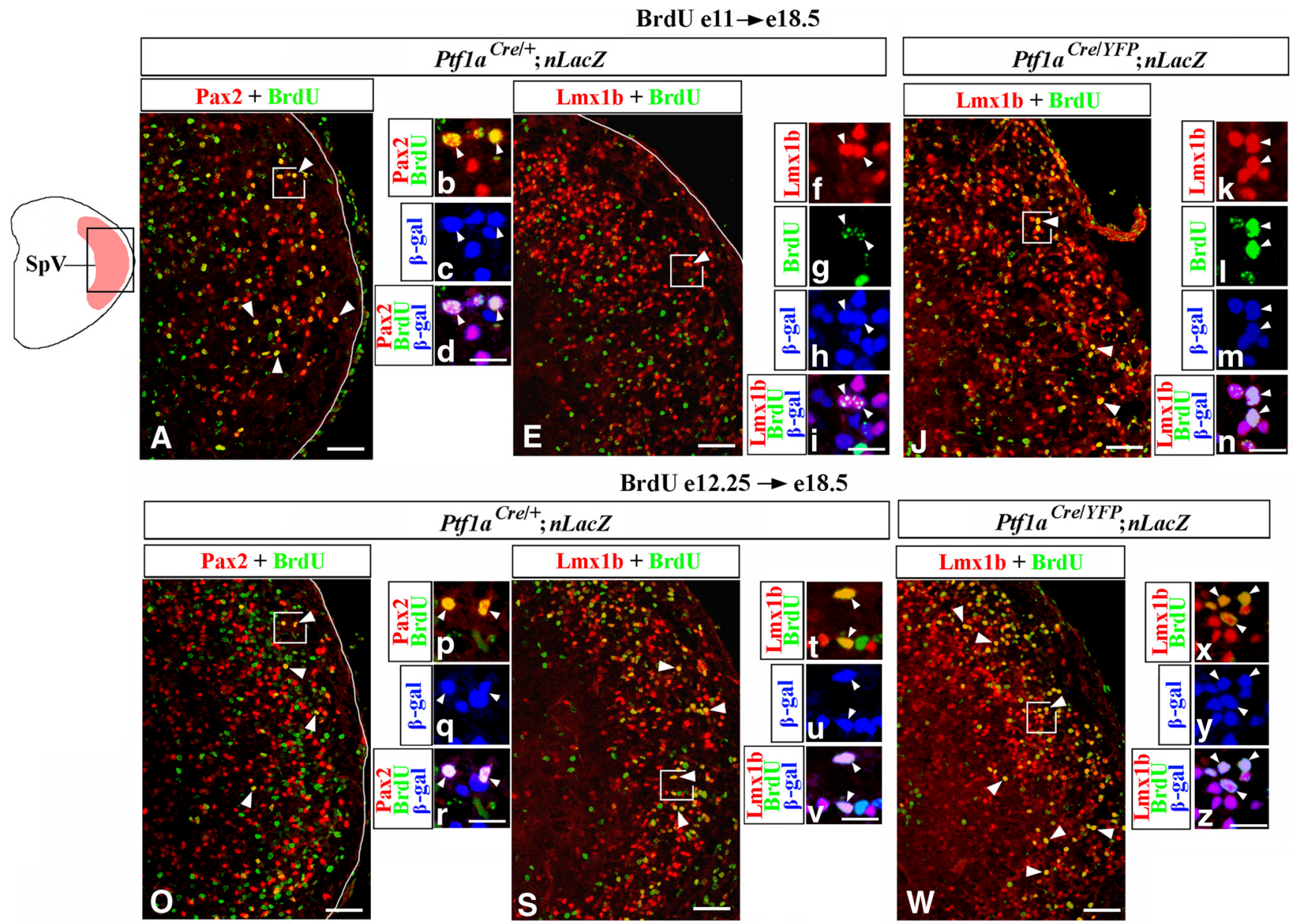

Lmx1b+/BrdU+ SpV cells

in e12.25 injected embryos,

fold change

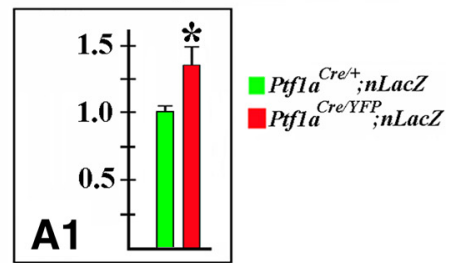

Figure 12. Birth-dating analysis of SpV neurons in $P t f 1 a^{-1-}$ mice. $\boldsymbol{A}-\mathbf{z}$, Transverse sections through the SpV nucleus with genotypes and antibody markers indicated. Mice were injected with BrdU at E11 $(\boldsymbol{A}-\boldsymbol{n})$ or E12.25 (0-z) and were analyzed at E18.5. Low-magnification panels correspond to the region boxed in the schematic. High-magnification panels correspond to areas boxed in adjacent data panels. In Ptf1a ${ }^{\text {cre/ }}{ }^{+} ;$LacZ (control) embryos, some Pax2 ${ }^{+}$SpV cells were labeled by BrdU, when BrdU was injected at both E11 and E12.25 (A, $\mathbf{O}$, arrowheads). In both cases, $\mathrm{Pax}^{+} / \mathrm{BrdU}{ }^{+}$cells coexpressed $\beta$-gal $\left(\boldsymbol{b}-\boldsymbol{d}, \boldsymbol{p}\right.$-r, arrowheads), indicating that these cells originate from Ptfla-expressing progenitors. $\boldsymbol{E}-\boldsymbol{i}$, Few $\mathrm{Lmx} 1 \mathrm{~b}^{+} / \mathrm{BrdU}^{+}$cells were detected in

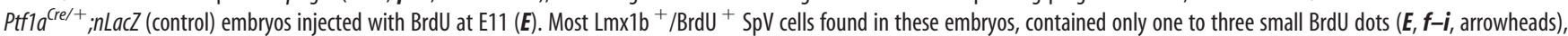
suggesting that since the time of BrdU incorporation they underwent one or two additional divisions before exiting the cell cycle. $J-n$, Many $\mathbf{L m x} 1 \mathrm{~b}^{+}$cells were heavily labeled with BrdU, when Ptf1a ${ }^{\text {CreYFP }}$; $n L a c Z$ (Ptf1a ${ }^{-1-}$ ) embryos were injected with BrdU at E11 ( $\boldsymbol{J}$, arrowheads). These cells coexpressed $\boldsymbol{\beta}$-gal ( $\boldsymbol{k}-\boldsymbol{n}$, arrowheads), indicating that they originated from Ptf1a-expressing progenitors. Thus, in contrast to control embryos, in Ptf1a ${ }^{-/-}$mutants, many cells arising from Ptf1a expressing progenitors at E11 adopt the fate of Lmx1b ${ }^{+}$SpV neurons. $\mathbf{S}-\mathbf{z}$, In both Ptf1a ${ }^{\text {Cre/+ }}$; nLacZ (control) and Ptf1 Ger/YFP, $n$ LacZ (Ptf1a ${ }^{-/-}$) embryos, some Lmx1b ${ }^{+}$cells were heavily labeled with BrdU, when BrdU was injected at E12.25 (S, W, arrowheads). In both cases, $\mathrm{Lmx} 1 \mathrm{~b}^{+} / \mathrm{BrdU}^{+} \mathrm{SpV}$ cells coexpressed $\beta$-gal ( $\boldsymbol{t}-\boldsymbol{V}, \boldsymbol{X}-\mathbf{Z}$, arrowheads), indicating that they originate from Ptf1a-expressing progenitors. $\boldsymbol{A} \boldsymbol{1}$, Cell counts revealed an increased number of $\mathrm{Lmx} 1 \mathrm{~b}^{+}$/ $\mathrm{BrdU}^{+} \mathrm{SpV}$ cells in Ptf1a ${ }^{-/-}$mutants injected with BrdU at E12.25 relative to control littermates $(p=0.0083)$, indicating that more $\mathrm{Lmx}_{1 \mathrm{~b}}{ }^{+} \mathrm{SpV}$ neurons arise in Ptf1a ${ }^{-/-}$mutants than in controls at E12.25. Scale bars: $\boldsymbol{A}, \boldsymbol{E}, \boldsymbol{J}, \mathbf{0}, \mathbf{S}, \boldsymbol{W}, 75 \mu \mathrm{m} ; \boldsymbol{b}-\boldsymbol{d}, \boldsymbol{f}-\boldsymbol{i}, \boldsymbol{k}-\boldsymbol{n}, \boldsymbol{p}-\boldsymbol{r}, \boldsymbol{t}-\boldsymbol{v}, \boldsymbol{x}-\mathbf{z}, 25 \mu \mathrm{m}$.

Previously, 10 newborn neuronal populations, dA1-4/dB1-4 and $\mathrm{dBLa} / \mathrm{b}$, were described in E11-E13 dorsal brainstem (Sieber et al., 2007). dA3 and dA4 cells were identified as newborn Lmx $1 b^{+} / \mathrm{Phox}_{2} \mathrm{~b}^{+} \mathrm{nTs}$ and ION neurons, respectively. $\mathrm{dBLb}$ cells in E12.5 rh7 were described as Lmx1b ${ }^{+} \mathrm{SpV}$ neurons (Sieber et al., 2007; Storm et al., 2009). Although the eventual fates of dB1 and dBLa cells were unknown, our data suggest that these two populations in caudal brainstem contain differentiating Pax2 ${ }^{+}$ GABAergic neurons of the nTs and SpV. Indeed, by combining birth-dating and fate-mapping studies, we find that $\mathrm{Pax}^{+}{ }^{+} \mathrm{nTs}$ and $\mathrm{SpV}$ neurons arise from $\mathrm{Ptfla}^{+}$progenitors during both early (E11) and late (E12.25) neurogenic phases, when the only $\mathrm{Pax}^{+}$populations arising from $\mathrm{Ptf} 1 \mathrm{a}^{+}$progenitors are $\mathrm{dB} 1$ and dBLa cells. 

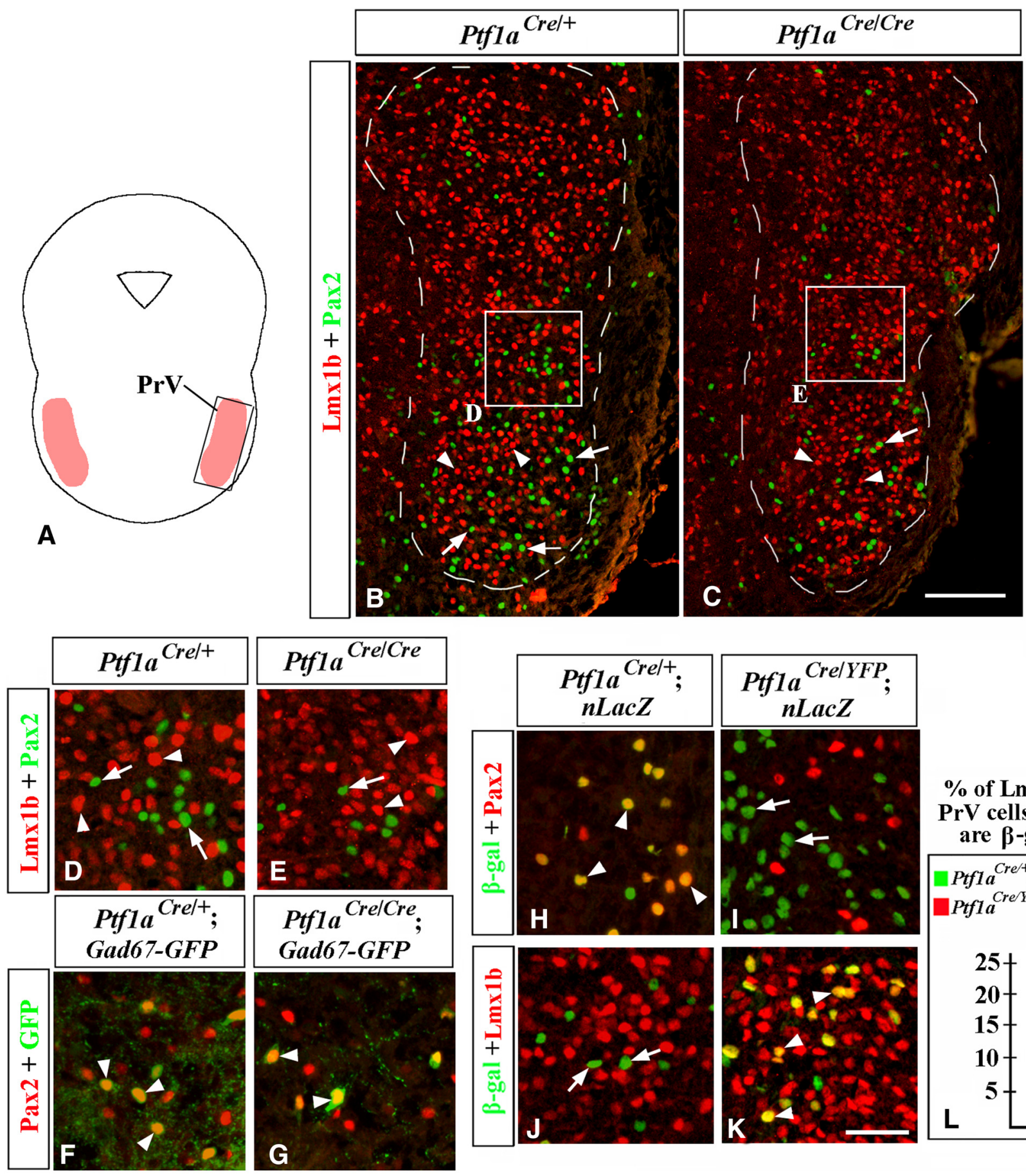

$\%$ of Lmx1b+

PrV cells that are $\beta$-gal+

Figure 13. In Ptf1a ${ }^{-1-}$ mutants, cell-fate misspecification leads to a reduction in but not a complete loss of Pax2 ${ }^{+}$PrV neurons. Transverse sections through the PrV nucleus with genotypes and antibody markers indicated. All images are from E18.5 embryos. $\boldsymbol{B}$ and $\boldsymbol{C}$ correspond to the region boxed in the schematic $\boldsymbol{A}$. The PrV nuclei are outlined by a dashed line. High-magnification images in $\boldsymbol{D}-\boldsymbol{K}$ correspond to the areas boxed in $\boldsymbol{B}$ and $\boldsymbol{C} . \boldsymbol{B}-\boldsymbol{E}$, Both $\mathrm{Lmx} 1 \mathrm{~b}^{+}$(arrowheads) and Pax2 ${ }^{+}$(arrows) PrV neurons were detected in control and Ptf1a ${ }^{-1-}$ mutants, although in Ptf1a mutants $\mathrm{Pax}^{+}$cells were reduced in number. $\boldsymbol{F}-\boldsymbol{G}$, In both control and Ptf1a ${ }^{-1-}$ Gad67-GFPmice, Pax2 ${ }^{+}$PrV neurons coexpressed GFP (arrowheads), indicating that they were GABAergic neurons. $\boldsymbol{H}-\boldsymbol{K}$, In the Ptf1a ${ }^{\text {Cre/ }}{ }^{+}$; LacZ (control) PrV nuclei, most $\beta$-gal ${ }^{+}$cells coexpressed Pax2 ${ }^{+}\left(\boldsymbol{H}\right.$, arrowheads) but not Lmx $1 \mathrm{~b}^{+}\left(\boldsymbol{J}\right.$, arrow), indicating that Pax ${ }^{+}$PrV neurons originate from Ptf1a-expressing

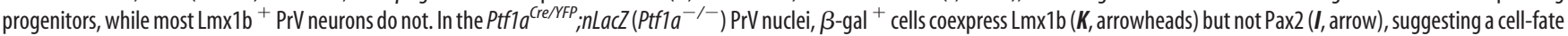

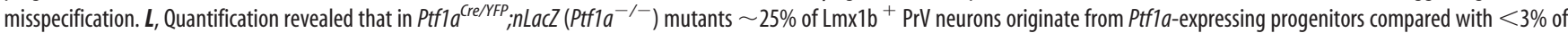
$\mathrm{Lmx1b}^{+}$PrV cells in Ptf1a ${ }^{\text {Cre/+}}$; $n$ LacZ control littermates $(p=0.0006)$. Scale bars: $\boldsymbol{B}, \mathbf{C}, 100 \mu \mathrm{m} ; \boldsymbol{D}-\boldsymbol{K}, 40 \mu \mathrm{m}$.

In E11.5 Ptfla ${ }^{-/-}$mutants, we detected neither $\mathrm{dB} 1$ nor dA4 neurons throughout rh2-7. Instead, rather than producing dA4/ $\mathrm{dB} 1$ neurons, in these mutants, Ptfla-expressing progenitors generate $\mathrm{Lmx} 1 \mathrm{~b}^{+} / \mathrm{Phox}_{2 \mathrm{~b}}{ }^{+}$and $\mathrm{Lmx} 1 \mathrm{~b}^{+} / \mathrm{Phox} 2 \mathrm{~b}^{-}$neurons (Figs. $2 U, 3 Q, 4 K)$. In Ptfla $a^{\mathrm{Cr} / \mathrm{Cre}} ; \mathrm{ROSA}-\mathrm{YFP}\left(\mathrm{Ptfla}^{-/-}\right)$caudal brainstem, ectopic Lmx1b ${ }^{+} / \mathrm{Phox}_{2} \mathrm{~b}^{+} / \mathrm{YFP}^{+} \mathrm{dA} 3$-like cells oc- cupied the area normally populated by newborn dA4 ION neurons, suggesting that, in the absence of Ptfla, dorsally located Ptfla-expressing progenitors generate dA3 cells instead of dA4 ION neurons (Figs. $2 U, 3 Q$ ). Thus, it is likely that previously reported ION loss in Ptfla ${ }^{-/-}$mice (Yamada et al., 2007) is caused by an early misspecification of dA4 ION neurons into dA3 
$\mathrm{Lmx}_{1} \mathrm{~b}^{+} / \mathrm{Phox} 2 \mathrm{~b}^{+}$cells. Consistent with transfating of dA4 ION neurons into $\mathrm{Lmx} 1 \mathrm{~b}^{+} / \mathrm{Phox} 2 \mathrm{~b}^{+} \mathrm{dA} 3$ cells at E11.5, in E18.5 $\mathrm{Ptfla}^{-/-}$embryos we observed excessive numbers of $\mathrm{Lmxlb}^{+} /$ Phox $2 \mathrm{~b}^{+}$nTs neurons, which, based on birth-dating analysis, aberrantly arose from $\mathrm{Ptfla}$-expressing progenitors during early neurogenesis. Lmx $1 b^{+} /$Phox $2 b^{-}$neurons aberrantly originating from Ptfla-expressing progenitors in E11.5 $\mathrm{Ptfla}^{-/-}$embryos, had the gene expression profile of somatosensory neurons. In E18.5 $\mathrm{Ptfla}^{-/-}$mutants, we detected excessive Lmx1b ${ }^{+} \mathrm{SpV}$ neurons, some of which, based on birth-dating analysis, arose from the Ptfla lineage during early neurogenesis. Thus, combining E18.5 and E11.5 analyses, we conclude that during early (E11.5) brainstem neurogenesis Ptfla regulates the production of $\operatorname{Pax} 2^{+}$viscerosensory and somatosensory neurons and ION neurons by segregating these lineages from $\mathrm{Lmxlb}^{+}$viscerosensory and somatosensory fates.

In contrast to wild-type E12.5 rh7, where $\mathrm{dBLa} / \mathrm{dBLb}$ neurons arise in a salt-and-pepper pattern (Sieber et al., 2007), in Ptfla ${ }^{-/-}$ E12.5 rh7, Pax2 ${ }^{+}$dBLa cells were absent while Lmx1b ${ }^{+}$dBLb neurons increased in number. A lack of changes in proliferation and apoptosis strongly suggests that the production of $\mathrm{dBLa} /$ dBLb cells in Ptfla $a^{-/-}$rh7 was affected by a cell-fate misspecification. Since both dBLa and dBLb cells normally arise from $P t f 1 a$-expresing progenitors, we could not use $P t f 1 a^{C r e} / R O S A$ fate mapping to directly demonstrate transfating of dBLa to $\mathrm{dBLb}$ cells. Birth-dating experiments revealed that in $\mathrm{Ptfla}^{-/-} \mathrm{mu}-$ tants, excessive $\mathrm{Lmxlb}^{+}$neurons born at E12.25, contribute to the SpV. Thus, our data support the conclusion that during late neurogenesis Ptf1a promotes the production of $\mathrm{Pax} 2{ }^{+}$viscerosensory and somatosensory neurons, and limits the excessive generation of $\mathrm{Lmxlb}^{+} \mathrm{SpV}$ neurons from Ptfla-expressing progenitors.

Unlike the nTs and SpV nuclei, which develop in caudal hindbrain (Sieber et al., 2007; D'Autréaux et al., 2011) and in Ptfla $a^{-1-}$ mutants lack Pax2 ${ }^{+}$GABAergic neurons, Pax ${ }^{+}$ GABAergic neurons in the $P t f 1 a^{-1-} \operatorname{PrV}$ nuclei were reduced in number but not lost. Interestingly, in $P t f 1 a^{-/-}$rh2-3, where PrV neurons arise (Oury et al., 2006), we observed a complete loss of $\mathrm{dA} 4 / \mathrm{dB} 1$ neurons and misspecification of the Ptfla lineage into $\mathrm{Lmx} 1 \mathrm{~b}^{+}$neurons, which is comparable to that in more caudal rhombomeres. In contrast to control $\mathrm{Ptfl} \mathrm{a}^{\mathrm{Cre} /+}$; $n L a c Z$ embryos, where $\operatorname{Pax} 2^{+} \operatorname{PrV}$ cells were $\beta$-gal ${ }^{+}$, in Ptf1a ${ }^{-/-}\left(\right.$Ptf1a $\left.{ }^{\text {Cre/YFP }} ; n L a c Z\right)$ mutants, Pax $2^{+}$PrV cells did not express $\beta$-gal. Therefore, it is likely that in Ptfla mutants Pax $2{ }^{+}$PrV cells belonging to the Ptfla lineage become misspecified, and their loss is partially compensated by Pax $2^{+}$ neurons originating from a $P t f 1 a^{-}$lineage, for example, dB4 cells, which express Pax2 but originate from $P t f 1 a^{-}$, more ventral progenitors (Fig. 4B-E).

In addition to viscerosensory, somatosensory, and ION defects, cochlear nuclei were also affected in Ptfla $a^{-/-}$embryos (Fujiyama et al., 2009). Cochlear neurons are born in rh2-5 (Landsberg et al., 2005), and a subset of them arises from Ptf1a-expressing progenitors (Fujiyama et al., 2009). It is possible that the cell-fate misspecification that we describe in rh2-5 (Fig. 3Q, 4K) contributes to the development of Ptfla $a^{-1-}$ cochlear abnormalities. Currently, however, it is not clear how cochlear neurons correlate with $\mathrm{dA} / \mathrm{dB}$ neurons in early rh2-5. Thus, additional studies are needed to determine whether Ptf1 a regulates the development of cochlear neurons by specifying their fate.

\section{Ptfla as a regulator of neurogenesis in the developing CNS}

Together with earlier Ptfla studies, our data argue that suppressing the $\mathrm{Lmxlb}^{+}$cell fate is a major function of Ptfla conserved throughout the CNS, highlighting the similarities of fundamental cell-fate specification mechanisms in different CNS regions. Although in $P t f 1 a^{-1-}$ hindbrain, a small fraction of Ptfla lineage cells were misspecified into cerebellar granule cells and mossy fiber neurons (Pascual et al., 2007; Yamada et al., 2007), which are not known to express $L m x 1 b$, the majority of Ptfla lineage cells in Ptf1a $a^{-/-}$mutants, including those in the cerebellum (Millen et al., 2014), spinal cord (Glasgow et al., 2005), and brainstem (this study) transfated to Lmx1b ${ }^{+}$ neurons, which normally arise adjacent to the Ptfla lineage in most CNS regions. Notably, even in rh2-6, where neurons originating from $\mathrm{Ptfla}{ }^{+}$progenitors are normally flanked by Phox $2 b^{+} / \mathrm{Lmx}_{1} \mathrm{~b}^{-} \mathrm{dB} 2$ cells, the loss of Ptf1a converts Ptf1a lineage cells into $\mathrm{Lmxlb}^{+}$rather than $\mathrm{dB} 2$ cells (Fig. 3Q, $4 \mathrm{~K}$ ). Since the loss of a single gene, Ptfla, converts large populations in the cerebellum, spinal cord, and rh2-7 into Lmx1b ${ }^{+}$ neurons, it is likely that $\mathrm{Lmxlb}^{+}$cell fate is a default fate in dorsal CNS caudal to the mid-hindbrain boundary.

The development of mammalian CNS is controlled by a hierarchy of transcription factors that, first, subdivide the VZ along the dorsal-ventral axis into discrete progenitor domains, such as bHLH Atoh1, Ngn1/2, and Ascl1 in the spinal cord. Additional genes then establish specific programs in neurons arising from each domain (Gowan et al., 2001; Gross et al., 2002; Gifford et al., 2013; Gray, 2013). Since in rh2-7 Ptfla is expressed in large progenitor domains producing multiple cell types, it is likely that Ptfla is located relatively high in the hierarchy of transcription factors controlling cell-fate specification in the brainstem. In the CNS, Ptfla regulates the fates of neurons generated in several distinct patterns of neurogenesis. In the cerebellum, Purkinje cells and molecular layer interneurons sequentially arise from the Ptflaexpressing cerebellar VZ; in early $\mathrm{rh} 2-7$, dA4/dB1 cells arise from spatially distinct domains in the $\mathrm{Ptf1}{ }^{+} \mathrm{VZ}$, while dBLa/ $\mathrm{dBLb}$ neurons arise in a salt-and-pepper pattern in later rh7. Several examples illustrate that Ptfla supports the production of distinct neuronal types by interacting with region-specific transcription factors. In the cerebellum, Gsxl acts as a switch from Ptf1a-dependent production of Purkinje cells to the generation of molecular-layer interneurons (Seto et al., 2014). In caudal hindbrain, Olig3 interacts with Ptfla during the differentiation of dA4 ION neurons (Storm et al., 2009). Additional studies are required to better understand temporal control of Ptfla-related neurogenesis and to identify additional regulators subdividing the Ptfla lineage into specific cell types.

In conclusion, we identify Ptfla as a major regulator of cellfate decisions in the mouse brainstem. Since homozygous PTF1A mutations were described in humans (Sellick et al., 2004), our study may help to delineate hindbrain pathology in these patients.

\section{References}

Abercrombie M (1946) Estimation of nuclear population from microtome sections. Anat Rec 94:239-247. CrossRef Medline

Blessing WW (1997) The lower brainstem and bodily homeostasis. New York: Oxford UP.

Borromeo MD, Meredith DM, Castro DS, Chang JC, Tung KC, Guillemot F, Johnson JE (2014) A transcription factor network specifying inhibitory versus excitatory neurons in the dorsal spinal cord. Development 141: 2803-2812. CrossRef Medline

Burlison JS, Long Q, Fujitani Y, Wright CV, Magnuson MA (2008) Pdx-1 
and Ptfla concurrently determine fate specification of pancreatic multipotent progenitor cells. Dev Biol 316:74-86. CrossRef Medline

Chattopadhyaya B, Di Cristo G, Higashiyama H, Knott GW, Kuhlman SJ, Welker E, Huang ZJ (2004) Experience and activity-dependent maturation of perisomatic GABAergic innervation in primary visual cortex during a postnatal critical period. J Neurosci 24:9598-9611. CrossRef Medline

Cheng L, Arata A, Mizuguchi R, Qian Y, Karunaratne A, Gray PA, Arata S, Shirasawa S, Bouchard M, Luo P, Chen CL, Busslinger M, Goulding M, Onimaru H, Ma Q (2004) Tlx3 and Tlx1 are post-mitotic selector genes determining glutamatergic over GABAergic cell fates. Nat Neurosci 7:510-517. CrossRef Medline

Chizhikov VV, Lindgren AG, Currle DS, Rose MF, Monuki ES, Millen KJ (2006) The roof plate regulates cerebellar cell-type specification and proliferation. Development 133:2793-2804. CrossRef Medline

Cordes SP (2001) Molecular genetics of cranial nerve development in mouse. Nat Rev Neurosci 2:611-623. CrossRef Medline

Dai JX, Hu ZL, Shi M, Guo C, Ding YQ (2008) Postnatal ontogeny of the transcription factor Lmxlb in the mouse central nervous system. J Comp Neurol 509:341-355. CrossRef Medline

Dauger S, Pattyn A, Lofaso F, Gaultier C, Goridis C, Gallego J, Brunet JF (2003) Phox $2 \mathrm{~b}$ controls the development of peripheral chemoreceptors and afferent visceral pathways. Development 130:6635-6642. CrossRef Medline

D’Autréaux F, Coppola E, Hirsch MR, Birchmeier C, Brunet JF (2011) Homeoprotein Phox $2 \mathrm{~b}$ commands a somatic-to-visceral switch in cranial sensory pathways. Proc Natl Acad Sci U S A 108:20018-20023. CrossRef Medline

Farago AF, Awatramani RB, Dymecki SM (2006) Assembly of the brainstem cochlear nuclear complex is revealed by intersectional and subtractive genetic fate maps. Neuron 50:205-218. CrossRef Medline

Fujiyama T, Yamada $\mathrm{M}$, Terao M, Terashima $\mathrm{T}$, Hioki $\mathrm{H}$, Inoue $\mathrm{YU}$, Inoue $\mathrm{T}$, Masuyama N, Obata K, Yanagawa Y, Kawaguchi Y, Nabeshima Y, Hoshino M (2009) Inhibitory and excitatory subtypes of cochlear nucleus neurons are defined by distinct bHLH transcription factors, Ptfla and Atoh1. Development 136:2049-2058. CrossRef Medline

Gifford WD, Hayashi M, Sternfeld M, Tsai J, Alaynick WA, Pfaff SL (2013) Spinal cord patterning. In: Comprehensive developmental neuroscience: patterning and cell type specification in the developing CNS and PNS (Rakic P, Rubenstein J, eds), pp 131-150. New York: Elsevier.

Glasgow SM, Henke RM, Macdonald RJ, Wright CV, Johnson JE (2005) Ptfla determines GABAergic over glutamatergic neuronal cell fate in the spinal cord dorsal horn. Development 132:5461-5469. CrossRef Medline

Gowan K, Helms AW, Hunsaker TL, Collisson T, Ebert PJ, Odom R, Johnson JE (2001) Crossinhibitory activities of Ngn1 and Math1 allow specification of distinct dorsal interneurons. Neuron 31:219-232. CrossRef Medline

Gray PA (2013) Transcription factors define the neuroanatomical organization of the medullary reticular formation. Front Neuroanat 7:7. CrossRef Medline

Gross MK, Dottori M, Goulding M (2002) Lbx1 specifies somatosensory association interneurons in the dorsal spinal cord. Neuron 34:535-549. CrossRef Medline

Hippenmeyer S, Vrieseling E, Sigrist M, Portmann T, Laengle C, Ladle DR, Arber S (2005) A developmental switch in the response of DRG neurons to ETS transcription factor signaling. PLoS Biol 3:e159. CrossRef Medline

Hori K, Cholewa-Waclaw J, Nakada Y, Glasgow SM, Masui T, Henke RM, Wildner H, Martarelli B, Beres TM, Epstein JA, Magnuson MA, Macdonald RJ, Birchmeier C, Johnson JE (2008) A nonclassical bHLH Rbpj transcription factor complex is required for specification of GABAergic neurons independent of Notch signaling. Genes Dev 22:166-178. CrossRef Medline

Hoshino M, Nakamura S, Mori K, Kawauchi T, Terao M, Nishimura YV, Fukuda A, Fuse T, Matsuo N, Sone M, Watanabe M, Bito H, Terashima T, Wright CV, Kawaguchi Y, Nakao K, Nabeshima Y (2005) Ptfla, a bHLH transcriptional gene, defines GABAergic neuronal fates in cerebellum. Neuron 47:201-213. CrossRef Medline

Huang X, Liu J, Ketova T, Fleming JT, Grover VK, Cooper MK, Litingtung Y, Chiang C (2010) Transventricular delivery of Sonic hedgehog is essen- tial to cerebellar ventricular zone development. Proc Natl Acad Sci U S A 107:8422-8427. CrossRef Medline

Jahagirdar V, Wagner CK (2010) Ontogeny of progesterone receptor expression in the subplate of fetal and neonatal rat cortex. Cereb Cortex 20:1046-1052. CrossRef Medline

Kawaguchi Y, Cooper B, Gannon M, Ray M, MacDonald RJ, Wright CV (2002) The role of the transcriptional regulator Ptfla in converting intestinal to pancreatic progenitors. Nat Genet 32:128-134. CrossRef Medline

Landsberg RL, Awatramani RB, Hunter NL, Farago AF, DiPietrantonio HJ, Rodriguez CI, Dymecki SM (2005) Hindbrain rhombic lip is comprised of discrete progenitor cell populations allocated by Pax6. Neuron 48: 933-947. CrossRef Medline

Maricich SM, Herrup K (1999) Pax-2 expression defines a subset of GABAergic interneurons and their precursors in the developing murine cerebellum. J Neurobiol 41:281-294. CrossRef3.0.CO;2-5 Medline

Millen KJ, Steshina EY, Iskusnykh IY, Chizhikov VV (2014) Transformation of the cerebellum into more ventral brainstem fates causes cerebellar agenesis in the absence of Ptfla function. Proc Natl Acad Sci U S A 111: E1777-E1786. CrossRef Medline

Nomaksteinsky M, Kassabov S, Chettouh Z, Stoeklé HC, Bonnaud L, Fortin G, Kandel ER, Brunet JF (2013) Ancient origin of somatic and visceral neurons. BMC Biol 11:53. CrossRef Medline

Oury F, Murakami Y, Renaud JS, Pasqualetti M, Charnay P, Ren SY, Rijli FM (2006) Hoxa2- and rhombomere-dependent development of the mouse facial somatosensory map. Science 313:1408-1413. CrossRef Medline

Pascual M, Abasolo I, Mingorance-Le Meur A, Martínez A, Del Rio JA, Wright CV, Real FX, Soriano E (2007) Cerebellar GABAergic progenitors adopt an external granule cell-like phenotype in the absence of Ptfla transcription factor expression. Proc Natl Acad Sci U S A 104:5193-5198. CrossRef Medline

Pattyn A, Morin X, Cremer H, Goridis C, Brunet JF (1997) Expression and interactions of the two closely related homeobox genes Phox2a and Phox 2b during neurogenesis. Development 124:4065-4075. Medline

Pickles JO (2015) Auditory pathways: anatomy and physiology. Handb Clin Neurol 129:3-25. CrossRef Medline

Qian Y, Fritzsch B, Shirasawa S, Chen CL, Choi Y, Ma Q (2001) Formation of brainstem (nor)adrenergic centers and first-order relay visceral sensory neurons is dependent on homeodomain protein Rnx/Tlx3. Genes Dev 15:2533-2545. CrossRef Medline

Qian Y, Shirasawa S, Chen CL, Cheng L, Ma Q (2002) Proper development of relay somatic sensory neurons and D2/D4 interneurons requires homeobox genes Rnx/Tlx-3 and Tlx-1. Genes Dev 16:1220-1233. CrossRef Medline

Rash BG, Tomasi S, Lim HD, Suh CY, Vaccarino FM (2013) Cortical gyrification induced by fibroblast growth factor 2 in the mouse brain. J Neurosci 33:10802-10814. CrossRef Medline

Rasmussen M, Kong L, Zhang GR, Liu M, Wang X, Szabo G, Curthoys NP, Geller AI (2007) Glutamatergic or GABAergic neuron-specific, longterm expression in neocortical neurons from helper virus-free HSV-1 vectors containing the phosphate-activated glutaminase, vesicular glutamate transporter-1, or glutamic acid decarboxylase promoter. Brain Res 1144:19-32. CrossRef Medline

Ruigrok TJ, Cella F (1995) Precerebellar nuclei and red nucleus. In: The rat nervous system, Ed 2, pp 277-308. New York: Academic.

Schambra U (2008) Prenatal mouse brain atlas. New York: Springer.

Schubert T, Huckfeldt RM, Parker E, Campbell JE, Wong RO (2010) Assembly of the outer retina in the absence of GABA synthesis in horizontal cells. Neural Dev 5:15. CrossRef Medline

Sellick GS, Barker KT, Stolte-Dijkstra I, Fleischmann C, Coleman RJ, Garrett C, Gloyn AL, Edghill EL, Hattersley AT, Wellauer PK, Goodwin G, Houlston RS (2004) Mutations in PTF1A cause pancreatic and cerebellar agenesis. Nat Genet 36:1301-1305. CrossRef Medline

Seto Y, Nakatani T, Masuyama N, Taya S, Kumai M, Minaki Y, Hamaguchi A, Inoue YU, Inoue T, Miyashita S, Fujiyama T, Yamada M, Chapman H, Campbell K, Magnuson MA, Wright CV, Kawaguchi Y, Ikenaka K, Takebayashi H, Ishiwata S, Ono Y, Hoshino M (2014) Temporal identity transition from Purkinje cell progenitors to GABAergic interneuron progenitors in the cerebellum. Nat Commun 5:3337. CrossRef Medline 
Sieber MA, Storm R, Martinez-de-la-Torre M, Müller T, Wende H, Reuter K, Vasyutina E, Birchmeier C (2007) Lbxl acts as a selector gene in the fate determination of somatosensory and viscerosensory relay neurons in the hindbrain. J Neurosci 27:4902-4909. CrossRef Medline

Soriano P (1999) Generalized lacZ expression with the ROSA26 Cre reporter strain. Nat Genet 21:70-71. CrossRef Medline

Srinivas S, Watanabe T, Lin CS, William CM, Tanabe Y, Jessell TM, Costantini F (2001) Cre reporter strains produced by targeted insertion of EYFP and ECFP into the ROSA26 locus. BMC Dev. Biol 1:4.

Storm R, Cholewa-Waclaw J, Reuter K, Bröhl D, Sieber M, Treier M, Müller T, Birchmeier C (2009) The bHLH transcription factor Olig3 marks the dorsal neuroepithelium of the hindbrain and is essential for the development of brainstem nuclei. Development 136:295-305. CrossRef Medline

Sudarov A, Turnbull RK, Kim EJ, Lebel-Potter M, Guillemot F, Joyner AL (2011) Ascl1 genetics reveals insights into cerebellum local circuit assembly. J Neurosci 31:11055-11069. CrossRef Medline

Swanson DJ, Steshina EY, Wakenight P, Aldinger KA, Goldowitz D, Millen KJ, Chizhikov VV (2010) Phenotypic and genetic analysis of the cerebellar mutant tmgc26, a new ENU-induced ROR-alpha allele. Eur J Neurosci 32:707-716. CrossRef Medline
Waite MR, Skaggs K, Kaviany P, Skidmore JM, Causeret F, Martin JF, Martin DM (2012) Distinct populations of GABAergic neurons in mouse rhombomere 1 express but do not require the homeodomain transcription factor PITX2. Mol Cell Neurosci 49:32-43. CrossRef Medline

Woolsey TA (1990) Peritheral alteration and somatosensory development. In: Development of sensory systems in mammals (Coleman JR, ed), pp 461-516. New York: Wiley.

Xiang CX, Zhang KH, Johnson RL, Jacquin MF, Chen ZF (2012) The transcription factor, Lmxlb, promotes a neuronal glutamate phenotype and suppresses a GABA one in the embryonic trigeminal brainstem complex. Somatosens Mot Res 29:1-12. CrossRef Medline

Yamada M, Terao M, Terashima T, Fujiyama T, Kawaguchi Y, Nabeshima Y, Hoshino M (2007) Origin of climbing fiber neurons and their developmental dependence on Ptfla. J Neurosci 27:10924-10934. CrossRef Medline

Yamada M, Seto Y, Taya S, Owa T, Inoue YU, Inoue T, Kawaguchi Y, Nabeshima Y, Hoshino M (2014) Specification of spatial identities of cerebellar neuron progenitors by ptfla and atoh1 for proper production of GABAergic and glutamatergic neurons. J Neurosci 34:4786-4800. CrossRef Medline 